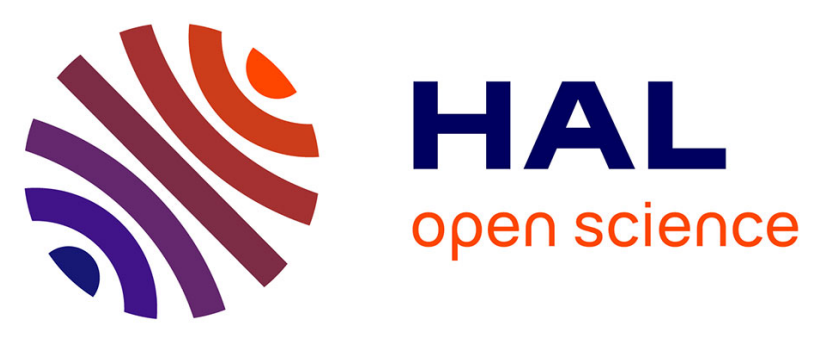

\title{
Inferring Interseismic Coupling Along the Lesser Antilles Arc: A Bayesian Approach
}

E. M. van Rijsingen, E. Calais, R. Jolivet, J. -B. de Chabalier, J. Jara, S. Symithe, R. Robertson, G. A. Ryan

\section{- To cite this version:}

E. M. van Rijsingen, E. Calais, R. Jolivet, J. -B. de Chabalier, J. Jara, et al.. Inferring Interseismic Coupling Along the Lesser Antilles Arc: A Bayesian Approach. Journal of Geophysical Research: Solid Earth, 2021, 126, 25 pp. 10.1029/2020JB020677 . insu-03590097

\section{HAL Id: insu-03590097 https://hal-insu.archives-ouvertes.fr/insu-03590097}

Submitted on 26 Feb 2022

HAL is a multi-disciplinary open access archive for the deposit and dissemination of scientific research documents, whether they are published or not. The documents may come from teaching and research institutions in France or abroad, or from public or private research centers.
L'archive ouverte pluridisciplinaire HAL, est destinée au dépôt et à la diffusion de documents scientifiques de niveau recherche, publiés ou non, émanant des établissements d'enseignement et de recherche français ou étrangers, des laboratoires publics ou privés.

\section{(1) (1) $\$$}

Distributed under a Creative Commons Attribution - NonCommercial - NoDerivatives| 4.0 


\section{JGR Solid Earth}

\section{RESEARCH ARTICLE \\ 10.1029/2020JB020677 \\ Key Points: \\ - We use geodetic observations to estimate interseismic coupling of the Lesser Antilles subduction zone using a Bayesian approach \\ - We find low to very low interseismic coupling, making it less likely that the 1839 and 1843 historical earthquakes were thrust events \\ - The Global Positioning System data also shows small, but detectable along-arc extension, consistent with observations of active normal faulting within the arc}

Supporting Information:

- Supporting Information S1

- Figure S10

Correspondence to:

E. M. van Rijsingen,

e.m.vanrijsingen@gmail.com

Citation:

van Rijsingen, E. M., Calais, E., Jolivet, R., de Chabalier, J.-B., Jara, J., Symithe, S., et al. (2021). Inferring interseismic coupling along the Lesser Antilles arc: A Bayesian approach. Journal of Geophysical Research: Solid Earth, 126, e2020JB020677. https://doi. org/10.1029/2020JB020677

Received 30 JUL 2020

Accepted 21 DEC 2020

\section{Inferring Interseismic Coupling Along the Lesser Antilles Arc: A Bayesian Approach}

\author{
E. M. van Rijsingen ${ }^{1}$ (D), E. Calais ${ }^{1,2}$ (D), R. Jolivet ${ }^{1,2}$ (D), J.-B. de Chabalier ${ }^{3}$, J. Jara ${ }^{1}$ (D) S. Symithe , $^{4}$, \\ R. Robertson ${ }^{5}$, and G. A. Ryan ${ }^{5,6}$ \\ ${ }^{1}$ Department of Geosciences, École Normale Supérieure, CNRS UMR 8538, PSL Université, Paris, France, ${ }^{2}$ Institut \\ Universitaire de France, Paris, France, ${ }^{3}$ Institut de Physique du Globe de Paris, CNRS UMR 7154, Université de Paris, \\ Paris, France, ${ }^{4}$ URGéo Laboratory, State University of Haiti, Port-au-Prince, Haiti, ${ }^{5}$ Seismic Research Center, University \\ of the West Indies, Saint Augustine, Trinidad and Tobago, ${ }^{6}$ Montserrat Volcano Observatory, Flemmings, Montserrat, \\ West Indies
}

Abstract The Lesser Antilles subduction zone is a challenging region when it comes to unraveling its seismogenic behavior. Over the last century, the subduction megathrust has been seismically quiet, with no large thrust event recorded, which raises the question whether this subduction zone is able to produce large interplate earthquakes or not. However, two historical earthquakes in the 19th century, a M 7-8 in 1839 and M 7.5-8.5 in 1843, are proposed to have occurred along the subduction megathrust, although no direct evidence exists. Here we provide a new assessment of interseismic coupling for the Lesser Antilles subduction zone, based on updated Global Positioning System (GPS) velocities and the latest models of the slab geometry and elastic crustal structure. We use a Bayesian approach, allowing us to explore the entire range of plausible models and to provide realistic estimates of interseismic coupling and associated uncertainties. We find low to very low coupling along the entire plate interface, including in the proposed rupture areas of the 1839 and 1843 events, where the sensitivity of our model is high. While a further understanding of temporal variations in interseismic coupling needs to be addressed in future studies, our results indicate that the Lesser Antilles subduction zone is uncoupled, which challenges the idea that the 1839 and 1843 earthquakes were thrust events. The updated GPS velocities of this work now also reveal a small, but detectable amount of along-arc extension, consistent with geological observations of active normal faulting within the arc.

Plain Language Summary The Lesser Antilles subduction zone forms the plate boundary where the North and South American plates sink underneath the overlying Caribbean plate. Such downgoing movement typically results in the buildup of stress along the frictional interface between the plates. When these stresses overcome the strength of the plate interface, they can be released through potentially devastating earthquakes. Using measurements from Global Navigation Satellite System stations on the islands of the Lesser Antilles, we model strain to determine how coupled the interface is. A high degree of coupling means that large "megathrust" earthquakes are likely, while low coupling means that big events are less likely and/or very rare. Two large earthquakes struck the Lesser Antilles in the 19th century, which have been interpreted to have occurred on the subduction interface. In this work we find a low to very low coupling along the plate interface, which implies that (1) these historical earthquakes are unlikely to have occurred on the subduction interface but rather deeper within the downgoing plate and (2) large, Tohoku-like, megathrust earthquakes are unlikely and/or must be very rare in the Lesser Antilles.

\section{Introduction}

An important, but originally unexpected, outcome of geodetic measurements at subduction plate boundaries over the past 20 years is that some are locked, therefore building-up elastic stresses to be released in large $\left(\mathrm{M}_{\mathrm{w}}>7.5\right)$ megathrust earthquakes, while others appear to slip aseismically at a rate close or equal to the plate convergence rate, without generating large events. The northern Honshu subduction zone in Japan is an example of the former, with a mechanically locked plate interface and resulting elastic strain measurable on land, as documented in the decades preceding the March 11, 2011, $\mathrm{M}_{\mathrm{w}} 9.0$ Tohoku-Oki earthquake (Loveless \& Meade, 2010, 2011; Mazzotti et al., 2000). The South Ecuador-North Peru 
segment of the South American subduction zone is an example of the latter, with a lack of large historical earthquakes and no marked elastic strain, indicative of a plate interface that is, mechanically uncoupled (Nocquet et al., 2014). The development of geodetic networks has provided crucial information that allows us to map with some detail the spatial—and sometimes temporal—variability in interplate coupling at subduction zones (e.g., Chlieh et al., 2008, 2011; Freymueller \& Beavan, 1999; Freymueller et al., 2000; Metois et al., 2016; Villegas-Lanza et al., 2016a, 2016b). Imaging, and understanding, the relationship between the degree of coupling of subduction plate boundary segments and their ability to produce-or not—megathrust earthquakes is of utmost importance to inform regional seismic hazard assessment (e.g., Loveless \& Meade, 2011; Stevens \& Avouac, 2016).

Subduction parameters proposed to play a role in tuning the seismogenic behavior of the megathrust include convergence velocity and slab age (Peterson \& Seno, 1984; Ruff \& Kanamori, 1980), seismogenic zone width and trench-parallel extent (Brizzi et al., 2018; Schellart \& Rawlinson, 2013), upper plate strain (Heuret et al., 2011, 2012), trench curvature (Schellart \& Rawlinson, 2013), internal density contrasts (Song \& Simons, 2003), curvature of the downgoing plate (Bletery et al., 2016; Schellart \& Rawlinson, 2013), trench sediment thickness (Heuret et al., 2012; Scholl et al., 2015), and subduction interface roughness (Das \& Watts, 2009; van Rijsingen et al., 2018). Although some of these parameters partially correlate with the global distribution of subduction megathrust earthquakes, some subduction zones remain poorly understood, in particular those that have been seismically quiet over the instrumental time period. Such regions are not devoid from significant events, but are referred to as quiet because no large thrust event has been recorded in the instrumental, and sometimes historical, period. To better understand the long-term seismogenic behavior of such quiet subduction zones, one must therefore rely on geological and historical records of large earthquakes, the distribution of microseismicity and repeating earthquakes, as well as interseismic coupling estimates inferred from geodetic measurements (Hough, 2013; Satake \& Atwater, 2007; Uchida \& Bürgmann, 2019; Wang \& Tréhu, 2016).

The Lesser Antilles subduction zone is one of these quiet subduction zones, with no thrust event larger than $\mathrm{M}_{\mathrm{w}} 6.5$ observed within the instrumental time interval. In fact, the four largest earthquakes recorded in the past 100 years $\left(M_{s} 7.51953 ; M_{s} 7.51969 ; M_{s} 7.41974\right.$; and $\left.M_{w} 7.42007\right)$ were all the result of normal faulting within the subducting slab or overriding plate (e.g., McCann et al., 1982). However, two large historical events in the 19th century, a M 7-8 event in 1839 and a M 7.5-8.5 in 1843 have been interpreted by some as interplate thrust events, although no direct evidence exists (Bernard \& Lambert, 1988; Feuillet et al., 2011; Hayes et al., 2014; Hough, 2013). If confirmed, this would be an indication that similar large interplate thrust earthquakes are to be expected in the future. In that case, according to current models of subduction zone seismogenic behavior showing that fault locking is a stable feature over at least thousands of years (Avouac, 2015; Jolivet et al., 2020; Mouslopoulou et al., 2016; Song \& Simons, 2003), it is reasonable to assume that 175 years after such large thrust events the Lesser Antilles plate interface should have relocked and that elastic strain should be visible in present-day surface deformation measurements.

Early Global Positioning System (GPS) measurements in the Caribbean showed that a geodetic site on Barbados island, well within the area that should experience the buildup of elastic strain if the plate interface was locked, was moving at a velocity consistent with that of the Caribbean plate (DeMets et al., 2000), indicative of very low coupling on the interface. Since then, thanks to the rapid development of geodetic observations in the Lesser Antilles, two studies have attempted to estimate interseismic coupling along the subduction interface (Manaker et al., 2008; Symithe et al., 2015), both finding very low values. However, uncertainties related to the distance of the GPS-stations from the trench, the nonuniqueness of the inversion, the crude estimation of coupling uncertainties and a limited data set all warrant a revision of this work with better data and a more advanced inversion technique.

In this study, we therefore determine the degree of interplate coupling on the Lesser Antilles subduction using updated GPS velocities and more accurate models of the slab geometry and the elastic structure of the crust, while adopting a Bayesian inversion approach. By exploring the entire range of model parameters, this approach provides an estimate of the interseismic coupling together with a probabilistic measure of its uncertainty. Our goal is to shed more light on the seismogenic behavior of the Lesser Antilles subduction and to discuss what this could mean for seismically quiet subduction zones in general. How does their 
short-term behavior relate to their ability to rupture in large megathrust earthquakes, and is there a physical mechanism that can explain their long-term aseismic character?

\section{Tectonic Setting}

The intraoceanic Lesser Antilles subduction zone forms the eastern boundary of the Caribbean plate (Figure 1). Since the Eocene, Atlantic oceanic crust of both the North- and South American plates has been subducting westward at a slow convergence rate of 18-20 mm/yr (DeMets et al., 2010). The Lesser Antilles arc is bounded to the north by the Anegada passage, an extensional fault system, also marking the eastern end of the Greater Antilles (Jany et al., 1990; Laurencin et al., 2017; Masson \& Scanlon, 1991). To the south, the Lesser Antilles arc abuts against the right-lateral El-Pilar-Central Range strike-slip fault zone that marks the boundary between the Caribbean and South American plates (Mann et al., 1990). With an azimuth of $\sim 251^{\circ}$, the subduction direction is almost arc-perpendicular in the center of the arc, while becoming more oblique toward the northern and southern edges.

As the subduction becomes more oblique in the north, the arcuate slab changes from dipping to the west underneath the Lesser Antilles, to plunging to the south below Hispaniola and Puerto Rico (Masson \&

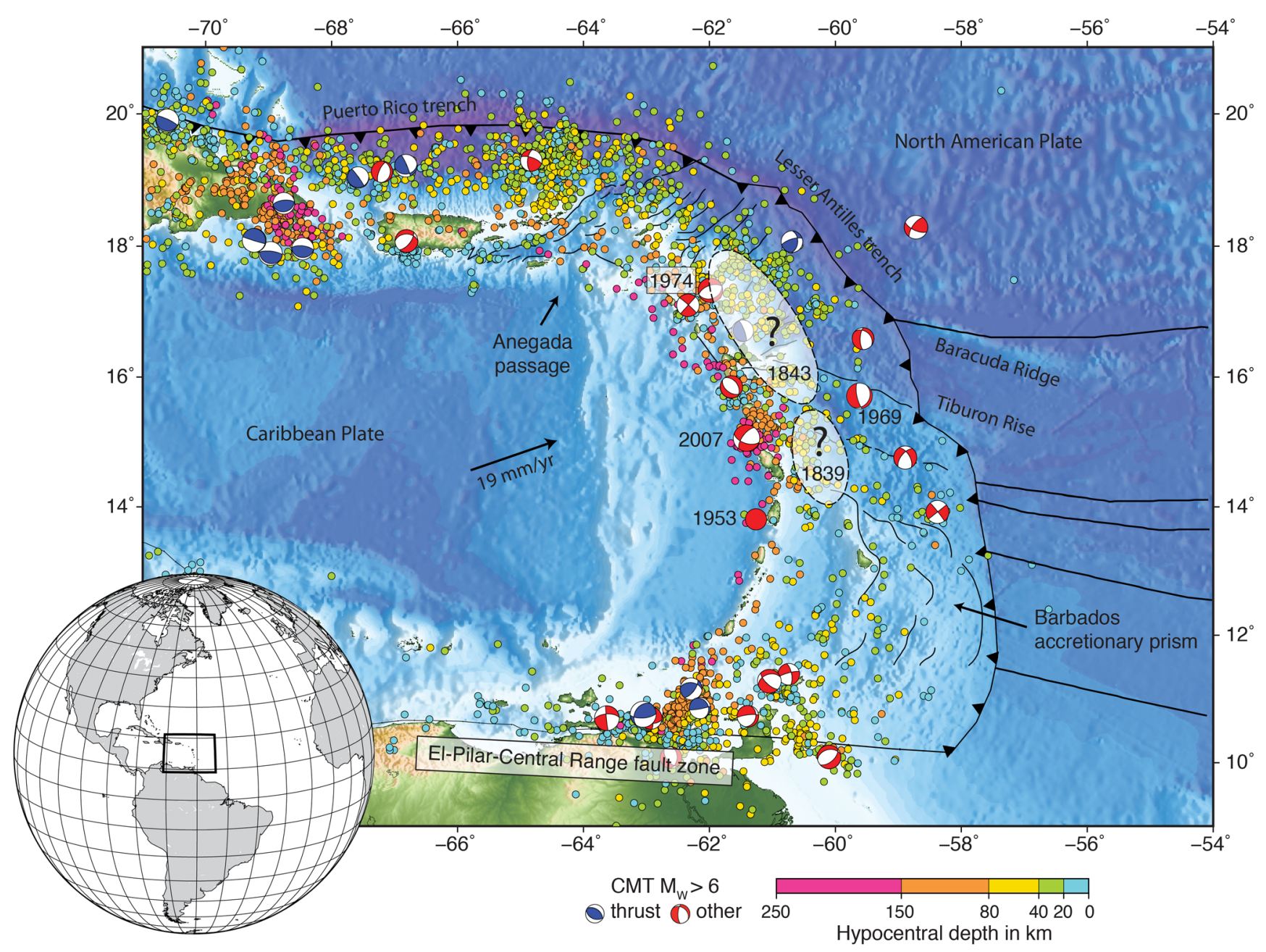

Figure 1. Seismotectonic setting of the Lesser Antilles subduction zone. Colored circles indicate seismicity ( $\left.\mathrm{M}_{\mathrm{w}} 4-6\right)$ from the USGS catalog, color coded as a function of depth. Global CMT Catalog (1976-2020) focal mechanisms are plotted in red and blue $\left(\mathrm{M}_{\mathrm{w}}>6\right)$. The white shaded areas represent the proposed rupture areas of the 1839 and 1843 historical earthquakes (e.g., Feuillet et al., 2011). The thin black lines indicate the faults mapped by Feuillet et al. (2002). For clarity, island names are indicated in Figure $2 b$. 
Scanlon, 1991; McCann \& Sykes, 1984). The transition between the North American and South American plates has been proposed to occur around $15^{\circ}$, where the existence of a slab gap at depth is debated (Patriat et al., 2011; Pichot, 2012; Schlaphorst et al., 2017; van Benthem et al., 2013). According to two recent models of the Lesser Antilles slab geometry, the shallow slab dip changes from $\sim 14^{\circ}$ in the north, to a shallower angle of $\sim 7^{\circ}$ toward the south (Bie et al., 2020; Hayes et al., 2018). Below the arc, the slab dips much more steeply, with some differences between the different slab models. For instance, in the central part of the subduction zone, the global Slab2 model (Hayes et al., 2018) estimates the slab surface to be up to $70 \mathrm{~km}$ shallower than the Bie et al. (2020) model.

The 850-km-long Lesser Antilles volcanic arc consists of 11 major volcanic islands and 19 small islands (the Grenadines) between Saint Vincent and Grenada in the south. The arc is constructed on thickened, $>150$ Ma old oceanic crust of the Caribbean plate (Mauffret \& Leroy, 1997), with estimates of crustal thickness varying between 21 and $35 \mathrm{~km}$ (Bie et al., 2020; Gonzáles et al., 2018; Schlaphorst et al., 2018). North of Martinique, the arc splits into two branches, with the inner arc (containing Saint Kitts, Saint Eustatius, and Saba) still volcanically active today. The islands of Antigua and Saint Martin are part of the remnants of the inactive outer arc (Bouysse \& Westercamp, 1990). Toward the south, the arc becomes narrower, more continuous and contains fewer volcanic islands.

With its slow convergence rate and old subducting lithosphere (80-100 Myr), the Lesser Antilles subduction zone is a global end-member (Stein et al., 1983). It is also an end-member in terms of incoming plate structure, as it consumes slow-spreading $(2 \mathrm{~cm} / \mathrm{yr})$ Atlantic lithosphere, while Pacific subduction zones consume much faster-spreading (up to $15 \mathrm{~cm} / \mathrm{yr}$ ) oceanic lithosphere (Müller et al., 2008). Several fracture zones, well-marked in the bathymetry, are entering the trench, as well as two elongated bathymetric highs, the Baracuda Ridge and the Tiburon Rise (Bouysse \& Westercamp, 1990; McCann \& Sykes, 1984; Stein et al., 1982), now interpreted as compressional structures within the $\sim 200 \mathrm{~km}$ wide transition zone between the North and South American plates (Patriat et al., 2011; Pichot, 2012). The sedimentary cover entering the subduction shows large variations in thickness and nature along the arc. In the south, the large influx from the Orinoco river built a 7-km-thick layer of mainly continental clastic sediments, that contributes in building the Barbados accretionary prism (Speed \& Larue, 1982). North of the Barracuda ridge, the seafloor is covered by only $200 \mathrm{~m}$ of dominantly pelagic marine sediments (Reid et al., 1996).

The forearc structure also shows a transition from north to south (Laigle et al., 2013). Its northern part shows mainly extensional features (Bouysse \& Guennoc, 1983; De Min et al., 2015), including trench-perpendicular normal faults, from a latitude of $\sim 15^{\circ}$ all the way up to the Anegada passage, which possibly represents the northernmost expression of this extensional system (Feuillet et al., 2002). South of $15^{\circ}$, the arc structure includes the Barbados accretionary prism extending up to $400 \mathrm{~km}$ eastward of the volcanic island chain, bounded to the west by a well-developed $150-\mathrm{km}$-wide fore-arc basin. This portion of the arc does not show the extensional structures observed in the north (Figure 1). The transition region between the north and south shows lateral ramps, following the same trend as the Barracuda Ridge and the Tiburon Rise (e.g., Brown \& Westbrook, 1987).

Current seismicity along the arc (Figure 1) shows that $\mathrm{M}_{\mathrm{w}}>4$ events are mostly focused in the northern part of the arc and around the El-Pilar-Central Range fault system all the way to the south. In addition to seismicity highlighting the westward plunge of the subducting slab, shallow seismicity occurs at crustal depths within the arc (i.e., $\leq 20-40 \mathrm{~km}$ ), particularly in the north. Seismicity is less prominent in the southern region that coincides with the sediment-rich Barbados accretionary wedge. Schlaphorst et al. (2016) analyzed seismicity patterns along the trench and found a high $b$-value (i.e., a higher fraction of small earthquakes) where fracture zones enter the trench. They did not observe a clear difference in $b$-value distribution between the northern and southern parts of the subduction zone. Bie et al. (2020) also found a possible link between seismicity and fracture zones, with abundant intermediate-depth intraslab seismicity beneath Martinique and Dominica, where the Marathon and Mercurius fracture zones subduct. This cluster of intraslab seismicity coincides with the location of the February $1906 \mathrm{M} 7.5$ and November $2007 \mathrm{M}_{\mathrm{w}} 7.4$ intermediate-depth events (Ruiz et al., 2013). A shallower cluster of small interplate thrust events (possibly repeating earthquakes; Laigle et al., 2013) has been observed offshore Martinique, at 40-50 km depth. The largest event in this cluster is the $2017 \mathrm{M}_{\mathrm{w}} 5.8$ Martinique earthquake. Bie et al. (2020) also observe pervasive seismicity in the cold mantle wedge corner, suggesting a deep decoupling depth between the slab and 
the upper-plate mantle (Wada \& Wang, 2009). This, in combination with the occurrence of the 2017 Martinique thrust event at $51 \mathrm{~km}$ depth suggests that the seismogenic zone may reach as far as $\sim 65 \mathrm{~km}$ depth.

\section{Methods}

\subsection{Geodetic Network and Data Processing}

The GPS data used in this work come primarily from continuous GPS sites, some of them installed within the COCONet project (Braun et al., 2012). Additional campaign measurements are available on some of the islands, mostly in Martinique and Guadeloupe. The 74 velocities used here are a subset of the 445 stations that we routinely process that cover the entire Caribbean region. A list of all stations and GPS velocities is available in the supporting information. The data processing procedure is the same as used in Symithe et al. (2015) and is only briefly summarized hereafter.

We use the GAMIT-GLOBK software package (Herring et al., 2010) to process the double-difference phase measurements using precise orbits and clocks from the International Global Navigation Satellite Systems (GNSS) Service (IGS), Earth orientation parameters from the International Earth Rotation Service (IERS) and to produce loosely constrained daily solutions. We then combine these regional solutions with global daily solutions for the whole IGS network available from the Massachusetts Institute of Technology IGS Data Analysis Center into weekly position solutions. These weekly solutions are finally combined into a single position/velocity solution, which we tie to the International Terrestrial Reference Frame (ITRF2014, Altamimi et al., 2016) by minimizing position and velocity deviations from a set of globally defined IGS reference sites common to our solution via a 12-parameter Helmert transform.

At continuous GPS sites, we use the First-Order Gauss-Markov Extrapolation algorithm (Herring, 2003; Reilinger et al., 2006) to obtain velocity uncertainties that account for time-correlated noise. For episodic sites, we include a $2 \mathrm{~mm} / \sqrt{y r}$ random walk component to account for colored noise in velocity uncertainties. Compared to the work of Symithe et al. (2015), the solution used here contains at least six additional years of data at the continuous sites. It also benefits from new GPS sites on some of the Lesser Antilles islands.

In order to be able to solve for coupling on the Lesser Antilles subduction interface, we rotate the velocities, originally expressed in ITRF, into a Caribbean-fixed reference frame. This operation is not trivial as (1) there are too few reliable GPS sites in the interior of the-mostly oceanic-Caribbean plate to reliably estimate an angular velocity and (2) using an a priori angular velocity from other publications-even that of Symithe et al. (2015)—would not insure consistency with our solution. We therefore performed a Caribbean-wide kinematic inversion using the "blocks" code (Meade \& Loveless, 2009) following the same methodology and model geometry as in Symithe et al. (2015) best-fit model. This procedure ensures an optimal definition of the Caribbean frame as it uses a regional minimization that includes all sites in the solution, does not require that we hand-select the sites that we a priori think belong to the Caribbean plate, and is fully consistent with our velocity solution.

Figure 2 shows GPS velocities in both the (a) Caribbean and (b) North American reference frame. Velocities in the Caribbean reference frame are very small, as found in previous studies (López et al., 2006; Manaker et al., 2008; Symithe et al., 2015). A new and intriguing aspect of this updated data set is an apparent along-arc extension, as sites in its northern part generally show NW-directed velocities (up to $2.3 \mathrm{~mm} / \mathrm{yr}$ ) and sites in its southern part show SSW-directed velocities (up to $1.9 \mathrm{~mm} / \mathrm{yr}$ ). These residual velocities appear significant at the $95 \%$ confidence interval at several of the continuous GPS sites present in the solution. In the central part of the arc, from Martinique to Guadeloupe, residual velocities in a Caribbean frame are more scattered but nonetheless show a general ocean-ward direction, particularly consistent at sites in the eastern-most part of Guadeloupe. We do not observe a systematic pattern of west-directed velocities, as one would expect if the plate interface was locked, even partially. This is quantified in more details below. 
(a)

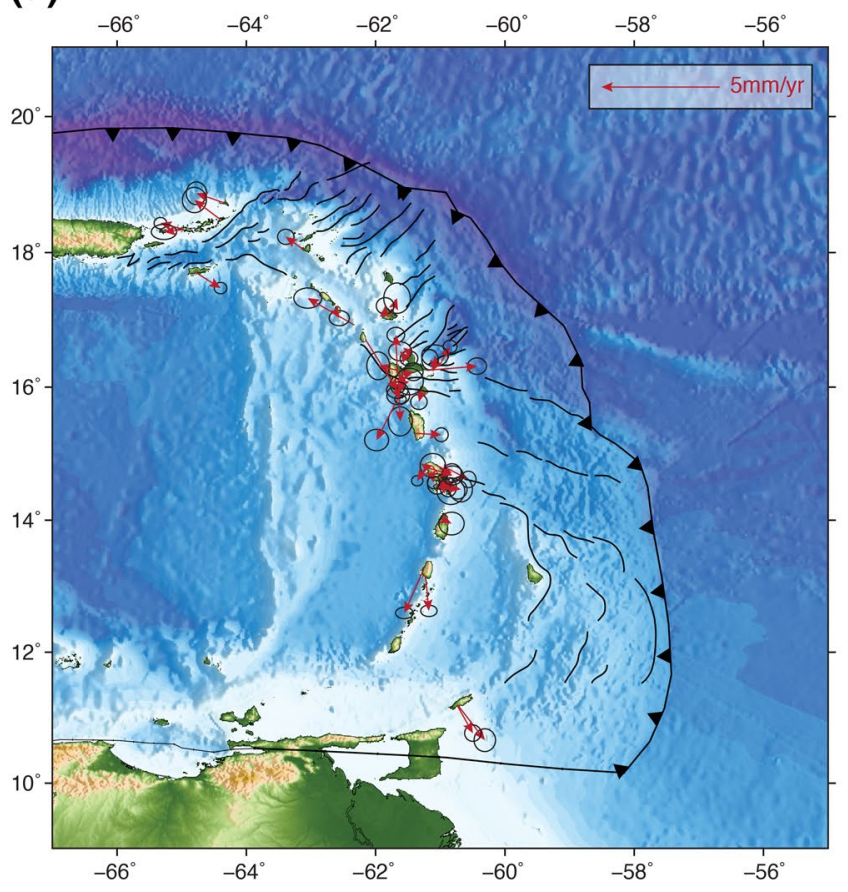

(b)

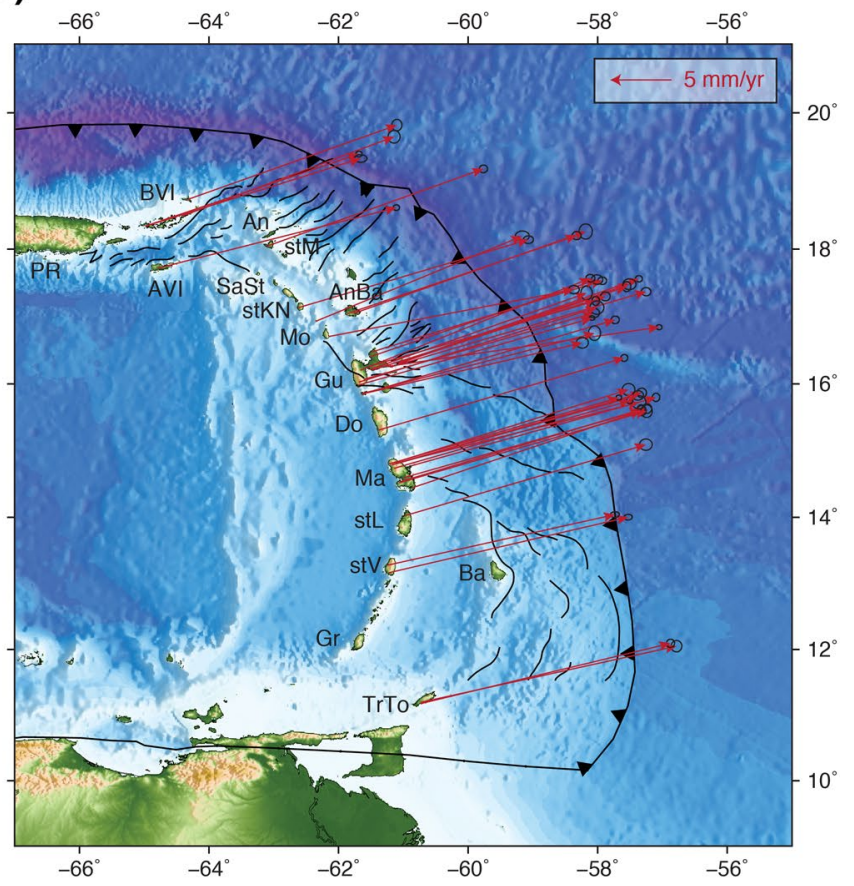

Figure 2. Global Positioning System (GPS) velocities in the (a) Caribbean and (b) North American reference frames. Only velocities with uncertainties below $0.25 \mathrm{~mm} / \mathrm{yr}$ are shown here for clarity, which is about $50 \%$ of the total data set. Figures of the complete data set can be found in the supplementary material. Error ellipses are 95\% confidence. PR, Puerto Rico; BVI, British Virgin Islands; AVI, American Virgin Islands; An, Anguilla; stM, Saint Martin; SaSt, Saba \& Saint Eustatius; AnBa, Antigua \& Barbuda; stKN, Saint Kitts \& Nevis; Mo, Montserrat; Gu, Guadeloupe; Do, Dominica; Ma, Martinique; stL, Saint Lucia; stV, Saint Vincent; Gr, Grenada; Ba, Barbados; TrTo, Trinidad \& Tobago.

\subsection{Inferring Interseismic Coupling}

To model interseismic coupling along the subduction interface, we invert GPS velocities using a Bayesian approach and a realistic geometry of the plate interface. Previous studies that used GPS velocities to estimate coupling used a planar subduction geometry, with a constant dip angle of $16^{\circ}$ (e.g., Symithe et al., 2015). Since then, more detailed models of the subduction interface have become available, allowing us to better account for the influence of fault geometry in the inversion process. Here we test two different fault geometries: the Slab2 model (Hayes et al., 2018) and a more recent model developed by Bie et al. (2020). We discretize the subduction interface into triangular elements, which vary in size from $2,500 \mathrm{~km}^{2}$ (i.e., $\sim 70 \mathrm{~km}$ side-length) below the islands, to $11,500 \mathrm{~km}^{2}$ (i.e, $\sim 150 \mathrm{~km}$ side-length) along the shallow parts of the fault. The size variability allows us to account for the increasing distance and hence decreasing model sensitivity between the fault and the island arc as one goes toward the trench.

We adopt a backslip approach to estimate interseismic coupling from geodetic displacement rates, in which deformation related to interseismic locking along the subduction interface is modeled by continuous slip of the locked part in a reverse sense compared to coseismic slip (Savage, 1983). We model the measured GPS velocities as the result of both interseismic coupling along the subduction interface and homogeneously distributed strain within the arc. The Green's functions that relate slip along the fault to displacement at the surface are calculated using a layered semi-infinite elastic medium (Zhu \& Rivera, 2002). We implement a crustal structure based on the four-layer velocity model proposed by Schlaphorst et al. (2018), who used receiver function inversions to obtain 1D velocity profiles for all islands along the Lesser Antilles arc (Figure 3). Based on the range of velocities they propose for each layer, as well as the velocities proposed by other models (Bie et al., 2020; Raffaele, 2012), we assume a 15\% uncertainty on the elastic parameters defining the overall crustal structure. 

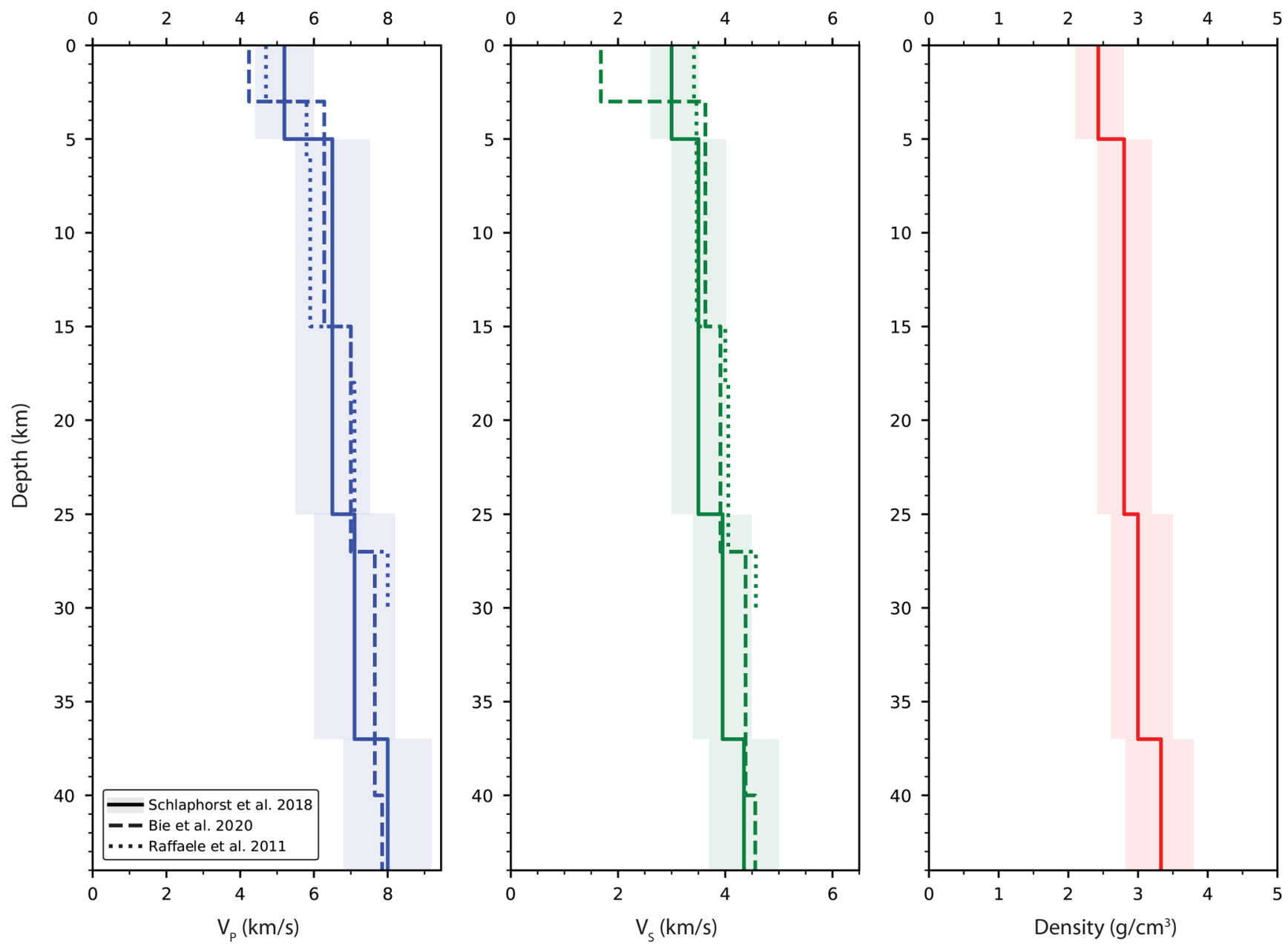

Figure 3. Crustal structure showing P-wave velocity $\left(V_{P}\right)$, S-wave velocity $\left(V_{S}\right)$ and density as a function of depth. The solid lines represent the model used in this study (based on Schlaphorst et al. [2018]). Shaded areas represent a 15\% uncertainty region. Several other models are indicated by the dashed lines.

The relation between the data measured at the surface and modeled slip along the fault can be described by the forward problem $\mathbf{d}=\mathbf{G m}$, where $\mathbf{d}$ represents the data vector containing the horizontal GPS velocities measured at the islands, $\mathbf{G}$ the Green's functions matrix (i.e., the matrix relating interseismic coupling to surface displacements) and $\mathbf{m}$ the vector of model parameters (i.e., the vector containing values of fault coupling for each fault element). The goal is to infer the distribution of model parameters (m) that is, consistent with our data (d). Because of data and model uncertainties and the uneven distribution of GPS sites at the surface, the solution to such an inverse problem is nonunique. Therefore, model uncertainties estimated in a least squares sense for the "best-fit" solution provide limited information on the actual quality of the fit of the data to the model. Instead of deriving a single solution of interseismic coupling, we adopt a Bayesian approach that explores the entire range of possible models and provides a probabilistic estimate of interseismic coupling (Minson et al., 2013). These estimates do not rely on any spatial smoothing and include a realistic approximation of uncertainties related to measurement and modeling errors. The ensemble of plausible models that fit the observations and are consistent with prior constraints are described by full posterior probability distributions. Such a probabilistic approach allows us to objectively assess the whole range of model parameters allowed by the data. Following Bayes' theorem, we write the posterior probability density function (hereafter PDF) of the model, $p(\mathbf{m} \mid \mathbf{d})$, as,

$$
p(\mathbf{m} \mid \mathbf{d}) \propto p(\mathbf{m}) \exp \left[-\frac{1}{2}(\mathbf{d}-\mathbf{G m})^{T} \mathbf{C}_{\chi}^{-1}(\mathbf{d}-\mathbf{G m})\right]
$$


where $p(\mathbf{m})$ represents the prior PDF of the model and $\mathbf{C}_{\chi}$ the misfit covariance matrix in the data space. The prior PDF describes our state of knowledge before considering the data. Here we use a uniform (boxlike) prior between 0 (i.e., the megathrust slips at plate convergence rate) and 1 (i.e., the megathrust is locked). We therefore assume no prior knowledge on the model parameters and an equal likelihood for all possible values of interseismic coupling.

The misfit covariance matrix $\mathbf{C}_{\chi}$ represents the sum of the data covariance matrix $\mathbf{C}_{d}$, describing the uncertainties on the data, $\mathbf{d}$, and the prediction error matrix, $\mathbf{C}_{p}$, which describes uncertainties of the model predictions such that:

$$
\mathbf{C}_{\chi}=\mathbf{C}_{d}+\mathbf{C}_{p}
$$

The quality of the model predictions, $\mathbf{C}_{p}$, is mainly influenced by the imperfect knowledge of the Earth structure (i.e., the elastic parameters $V_{p}, V_{s}$, and $\rho$ ). In order not to overfit the data and produce reasonable estimates of coupling uncertainties along the fault, we need a careful description of errors. For this, we use a stochastic forward model developed by Duputel et al. (2014), based on a linear formulation of the prediction uncertainty. Rather than providing a single set of predictions for a given source model, as would be done in a deterministic approach, this stochastic formulation produces a distribution of predictions for a given uncertainty in the elastic structure (i.e., 15\%, as indicated above).

Since we are dealing with a high-dimensional model space, the solution of our inverse problem cannot be characterized using analytical techniques or simple Metropolis-like sampling. We therefore explore the model space in a random manner, sampling the posterior PDF, $p(\mathbf{m} \mid \mathbf{d})$, using AlTar, a parallel Markov Chain Monte Carlo (MCMC) algorithm based on the Cascading Adaptive Transitional Metropolis in Parallel (CATMIP) algorithm (Minson et al., 2013). The MCMC method uses a random walk to explore the model space and probabilistically determines whether to take a certain step or not. AlTar runs thousands of these MCMC chains in parallel, in order to efficiently and exhaustively sample the model space. Rather than sampling the posterior PDF immediately, a transitioning approach is used, thereby first sampling the prior PDF, $p(\mathbf{m})$, and then slowly increasing the information brought by the data until the posterior PDF is sampled. Computational tractability is ensured via the use of multiple Graphics Processing Units (GPUs) in parallel.

Finally, we end up with an ensemble of 150,000 models drawn from the posterior PDF. From these models, we can explore various statistical properties, such as the mean, mode, standard deviation, kurtosis, skewness, and information gain (i.e., with respect to the prior). In addition, we can explore the probability densities for each fault element individually (i.e., the marginal PDF's).

\section{Results}

In the following sections, results from several analyses regarding interseismic coupling along the subduction megathrust will be discussed. We present the model sensitivity (Section 4.1.), some simple forward models to understand what our model would predict for various coupling scenarios (Section 4.2.), the posterior PDF resulting from the Bayesian inversion (Section 4.3.), a comparison between two different slab geometry models (Section 4.4.) and some specific tests regarding the historical 1839 and 1843 earthquakes (Section 4.5.). Except for Section 4.4, all results are based on the slab geometry from the Slab2 model (Hayes et al., 2018), although Section 4.4 will demonstrate that similar results would be observed when using the slightly steeper slab geometry recently proposed by Bie et al. (2020).

\subsection{Model Sensitivity}

In order to evaluate the robustness of the fault coupling estimates, we compute the sensitivity, $\mathbf{S}$, of the model to the GPS data set, defined as,

$$
\mathbf{S}=\operatorname{diag}\left(\mathbf{G}^{t} \mathbf{G}\right)
$$




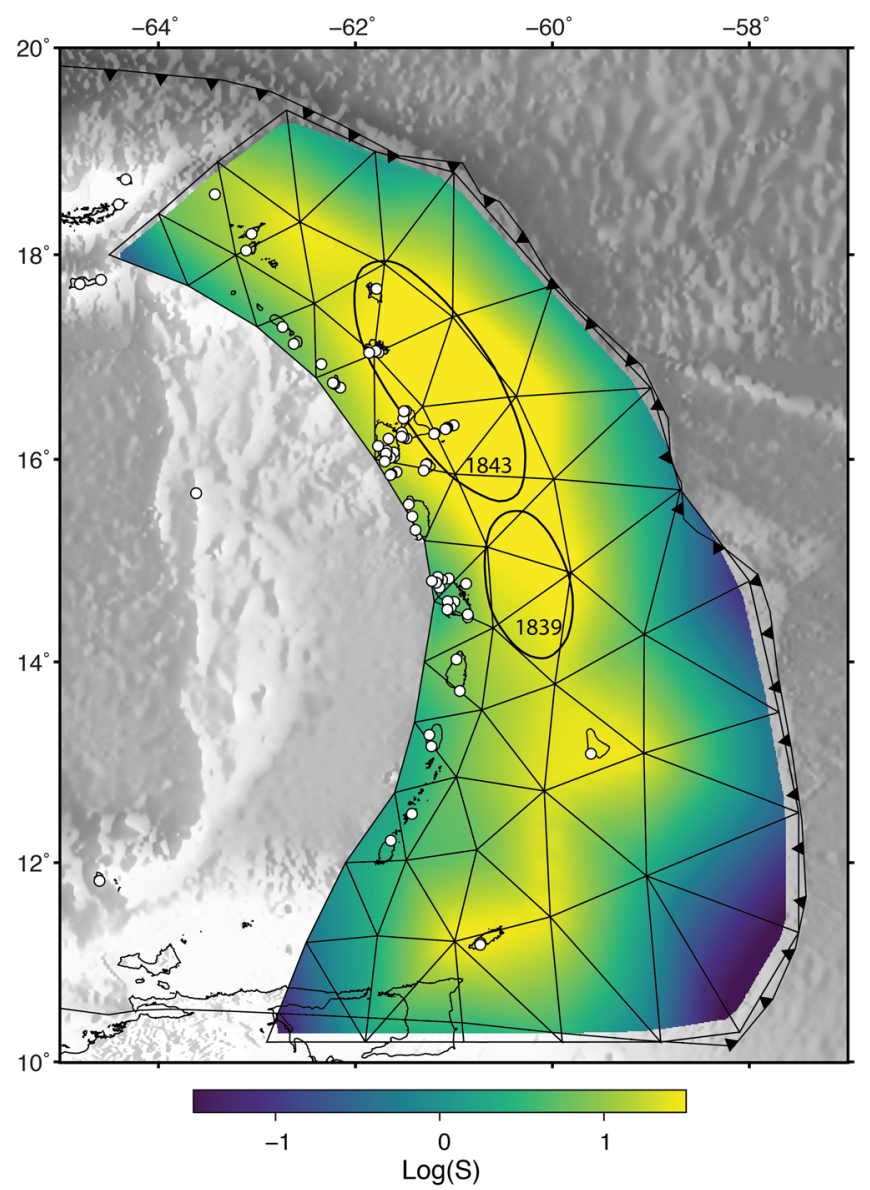

Figure 4. Model sensitivity (based on the Slab2 geometry), describing how well the GPS stations on the islands (white dots) can constrain the plate interface behavior. Each node is colored by the sum of the displacement at the GPS stations, due to unit coupling along that node. where $\mathbf{G}$ is the Green's functions matrix defined previously and diag is the diagonal operator that extracts the diagonal after multiplication (Lin et al., 2015; Loveless \& Meade, 2011). For each node of the fault, $\mathbf{S}$ describes the sum of squared displacements at all data locations resulting from a coupling of 1 on that specific node. The sensitivity therefore indicates the relative contribution of each node to the prediction of surface displacements. It provides a useful estimate of the extent to where the data is able to inform the posterior PDF of the model, and where it will hence differ the most from the uniform prior PDF. Nodes located further away from data locations are generally expected to have lower sensitivity and will usually have larger uncertainties in the posterior PDF.

Figure 4 shows the model sensitivity, based on the Slab2 geometry (Hayes et al., 2018) and the elastic structure presented previously (Schlaphorst et al., 2018). We observe a higher sensitivity for the central part of the seismogenic zone, between 25 and $60 \mathrm{~km}$ depth. The region offshore Guadeloupe and Dominica has the highest sensitivity, which is also where the 1839 and 1843 earthquakes are proposed to have occurred. As expected, we find the lowest sensitivity closest to the trench, as these nodes are the furthest away from the data locations. This is particularly the case for the southern part of the subduction zone, where the slab dip is shallower (i.e., $\sim 7^{\circ}$ with respect to $\sim 14^{\circ}$ in the North) and the trench is located $\sim 200 \mathrm{~km}$ further to the East with respect to the arc. A locally high sensitivity is however found below the islands of Barbados and Tobago, which is most likely related to the relatively close distance between the fault and the stations on these islands due to the shallow slab dip. We find a similar pattern of model sensitivity when using the Bie et al. (2020) fault geometry (Figure S2 in the supporting information). We also include supplementary figures exploring different distributions of data locations, which highlight the importance of seafloor stations for improving sensitivity along the shallow parts of the megathrust (Figures S3 and S4), as well as a matrix showing the distance between the fault nodes and GPS station (Figure S5). The latter indicates that nodes with higher sensitivity are indeed located closer to the data points.

\subsection{Simple Forward Models}

We start our search for a better understanding of the distribution of interseismic coupling by manually exploring forward models in order to develop an intuition on the velocity magnitudes to expect for certain scenarios of interplate coupling. We test an interface that is, either homogeneously or partially (i.e., 50\%) locked down to a depth of (1) $20 \mathrm{~km}$, representing the shallowest part of the subduction interface or (2) $65 \mathrm{~km}$, currently believed to represent a minimum downdip limit of the seismogenic zone (Bie et al., 2020).

Figure 5 shows the forward models and the resulting predictions. The model with full coupling down to $20 \mathrm{~km}$, predicts westward velocities of 1-2 mm/yr at the islands that are closest to the trench (i.e., Barbados in the south, and Barbuda, Saint Martin and Anguilla in the north). The actual observations on these islands are similar in magnitude, but are oriented in a trench-parallel direction (i.e., toward the northwest and south) rather than trench-perpendicular as the response to interplate coupling shows. This indicates that despite the relatively low sensitivity for these shallow parts of the plate interface, a fully coupled interface down to $20 \mathrm{~km}$ depth would be detected by the stations on the above-mentioned islands. This is less clear however, for 50\% coupling within this depth range. In the case of an interface coupled down to $65 \mathrm{~km}$ depth, the synthetics are clearly inconsistent with the observed GPS velocities, both for the fully and partially coupled scenarios. With an interface that is, fully coupled, the synthetics indicate westward velocities at all stations, that reach up to $15 \mathrm{~mm} / \mathrm{yr}$, about 7 times larger than observations. 
(a)

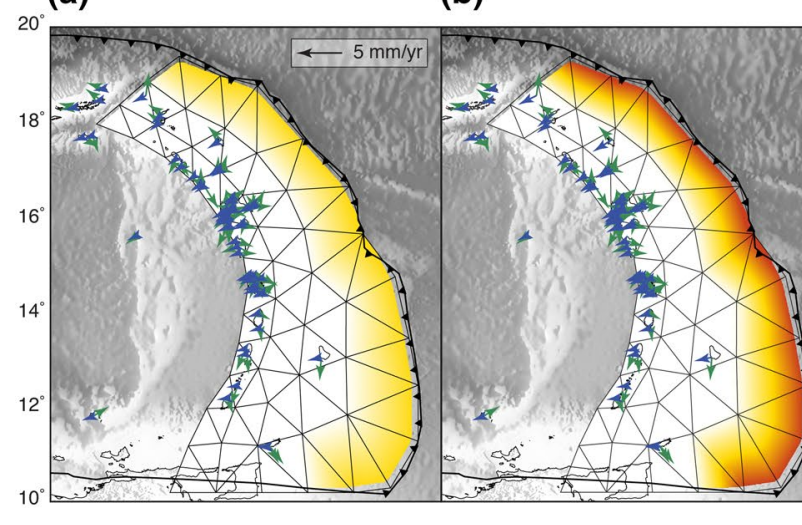

(c)

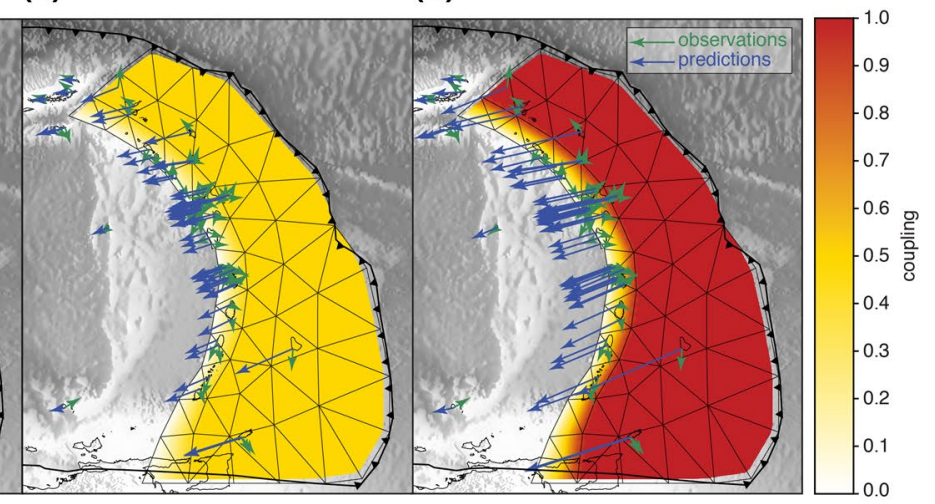

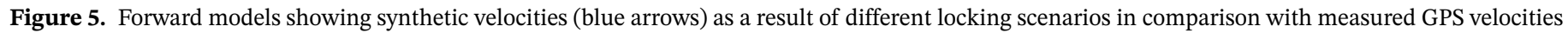

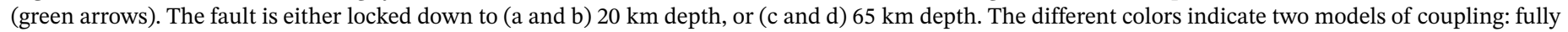
locked (i.e., coupling $=1.0$ ) and 50\% locked (i.e., coupling $=0.5$ ).

These forward models indicate that both a partially and a homogeneously locked interface down to $65 \mathrm{~km}$ depth are very unlikely. A fully locked interface down to $20 \mathrm{~km}$ also seems unlikely, due to the difference in orientation between data and predictions for islands closer to the trench. However, a partial (less than 40\%) locking along the shallow parts of the megathrust cannot be excluded based on these first tests.

\subsection{Posterior Interseismic Coupling Distribution}

We now discuss the results of the Bayesian inversion, where Figure 6a shows the distribution of coupling corresponding to the mean of the posterior PDF. In general, the inferred coupling is very low $(<0.2)$, especially in the central parts of the seismogenic zone, where we also observe the highest sensitivity (Figure 4). Along the shallower parts of the interface, we find a mean coupling of 0.2, while along the deeper parts (i.e., $>60 \mathrm{~km}$ ) mean coupling varies between zero around the islands of Saint Kitts \& Nevis, to 0.5 below Martinique and a local high of 0.7 west of the Grenadines. Figure $6 \mathrm{~b}$ shows the mode of the posterior PDF, highlighting the most common values of coupling derived from the marginal PDF for each node. It shows zero coupling everywhere, except for two local highs along the deeper part of the subduction interface (i.e., 60-100 km), one below Martinique (coupling of 0.5), and one west of the Grenadines (coupling of 0.8).

Both the mean and mode of the posterior PDF only provide part of the information on the estimated interseismic coupling, as one also needs to consider the width of the distribution for each node and how much the posterior PDF has evolved from a uniform prior with a mean coupling of 0.5. This can be better understood by looking at the marginal PDFs for each individual node (nodes 1-5 in Figure 6a). Nodes 1, 2 , and 5 show distributions with the highest probability around a coupling of 0 , with an especially narrow distribution for node 2, located in the region with highest sensitivity (Figure 4). Node 3 shows a wide PDF centered around 0.5, meaning that it has evolved the least from the uniform (box-like) prior PDF. Node 4 shows a PDF with a peak near a coupling value of 1 , while surrounding nodes have their highest probability concentrated around 0 again. Because the depth of both nodes 3 and 4 (i.e., $100 \mathrm{~km}$ ) places them below the downdip limit of the seismogenic zone, we interpret these values as outliers along a generally uncoupled interface. They could be a consequence of the model trying to best fit some of the southward GPS velocities on the islands. Figure S7 in the supporting information confirms this by showing southward oriented surface predictions related to a forward model where only these two nodes are fully locked. Residuals between observed and predicted velocities based on the mean posterior PDF can be found in Figure 7a. Observations and model predictions generally agree well in terms of velocity magnitude, though not always in direction. It is however difficult to compare velocities that are in the $0.2-2 \mathrm{~mm} / \mathrm{yr}$ range with $95 \%$ confidence uncertainties that are often close to the observed signal. The posterior mean and mode coupling models for the slab geometry by Bie et al. (2020) can be found in the supporting information (Figure S6). 
(a)

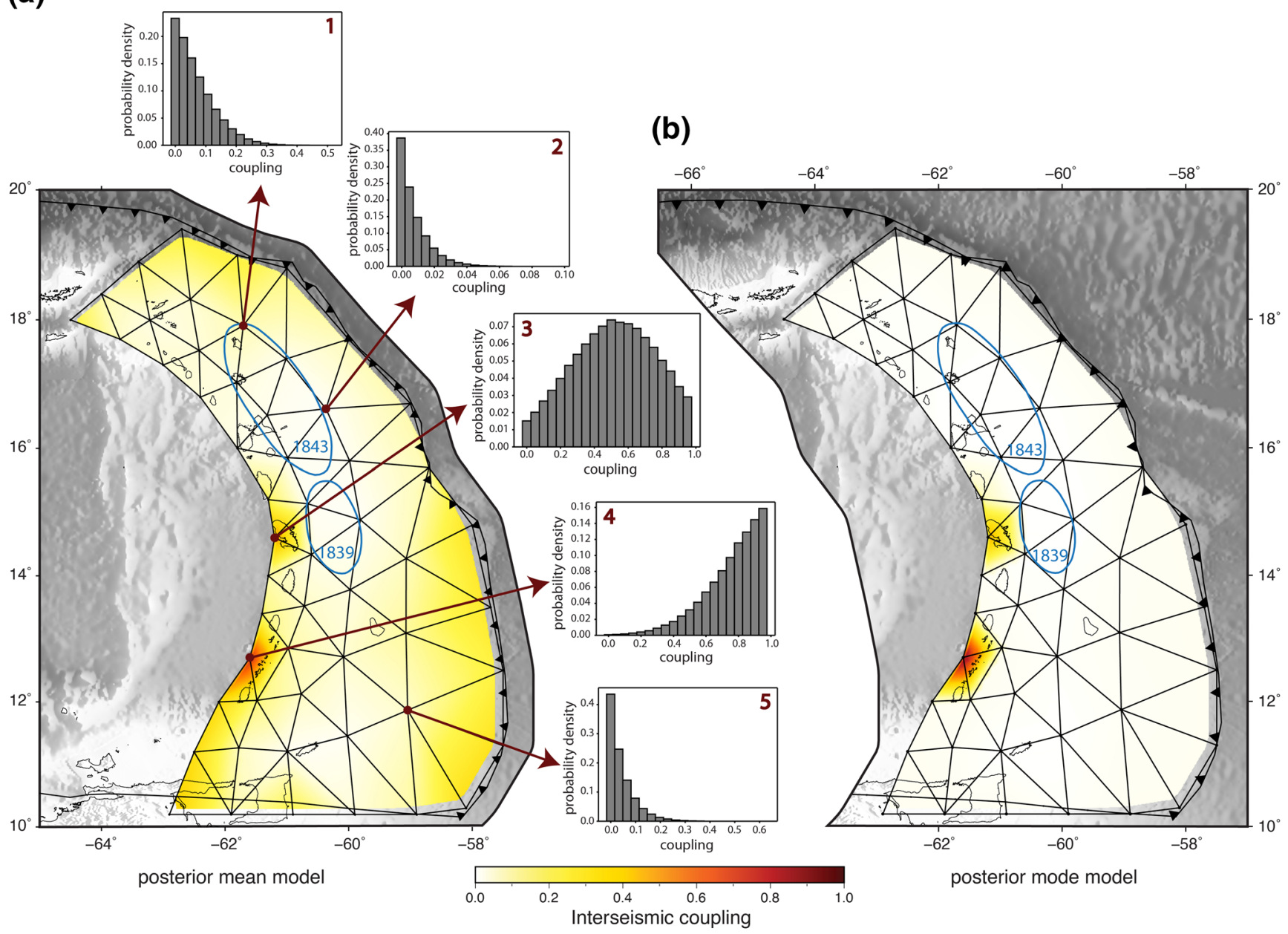

Figure 6. (a) Posterior mean and (b) mode coupling models for the Slab2 geometry. The inversion provides probability density distributions for each node of the triangular mesh, of which the mean and mode values are shown in the two maps. The marginal probability densities for several nodes are shown as well. The blue contours indicate the proposed rupture contours of the historical 1839 and 1843 earthquakes.

In order to account for the along-arc extension pattern observed in the GPS velocities described above, we jointly solve for homogeneously distributed surface strain together with the plate interface coupling. We estimate a single horizontal strain rate tensor (i.e., three unknowns) for the whole arc in order to limit the number of parameters to be inverted for. Figure $7 \mathrm{~b}$ shows the principal axes of the strain rate tensor, as well as the estimated velocities related to this extension at the GPS sites. Although these velocities are quite low (i.e., $<0.7 \mathrm{~mm} / \mathrm{yr}$ ), a clear pattern of north-south extension emerges. This indicates that the GPS data do contain the extension observed geologically along the arc (Bouysse \& Guennoc, 1983; De Min et al., 2015; Feuillet et al., 2002; Münch et al., 2014) and can now provide a quantitative estimate of the slip rate on intra-arc normal faults. The results from this inversion indicate that the total amount of fault slip is unlikely to exceed $1 \mathrm{~mm} / \mathrm{yr}$, though a proper estimate would require discretizing the strain rate estimation. We are however limited by the number and location of islands. We note that the strain rate tensor also indicates a trench-perpendicular component of extension, although this is less well resolved due to the north-south alignment of the islands, and of the data points. We explore a potential tradeoff between this arc-perpendicular extension and interseismic coupling in Figure S8, and find no indication for this. 
(a)

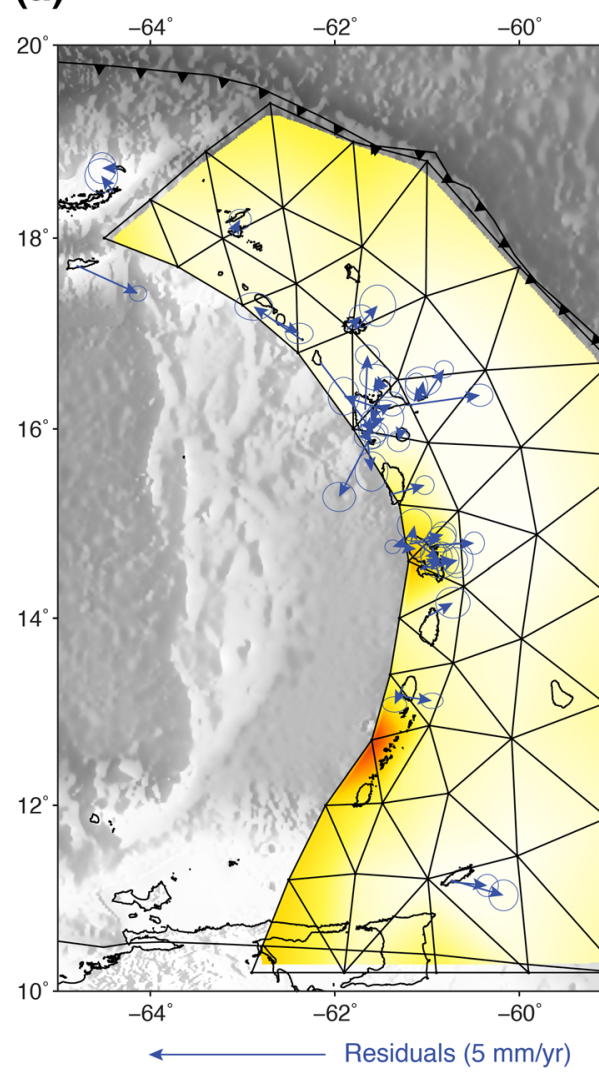

(b)

$-58^{\circ}$

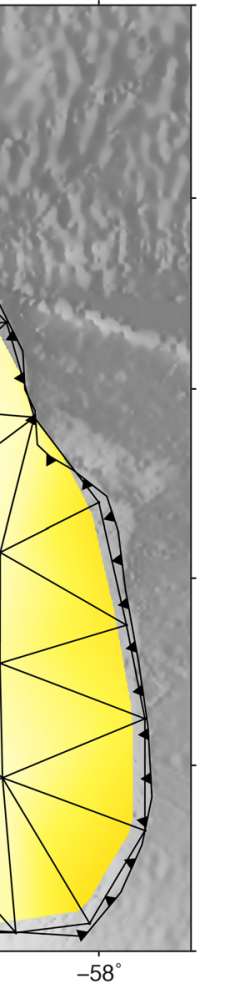

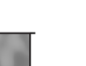

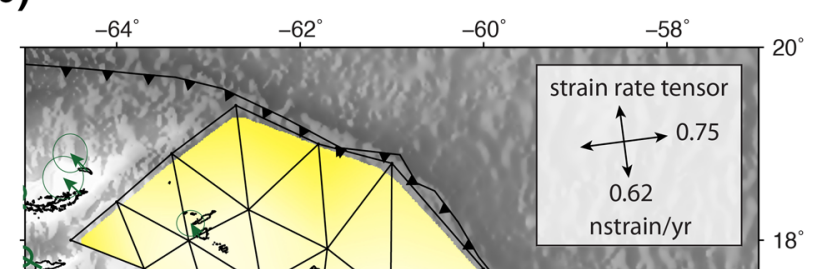

$18^{\circ}$

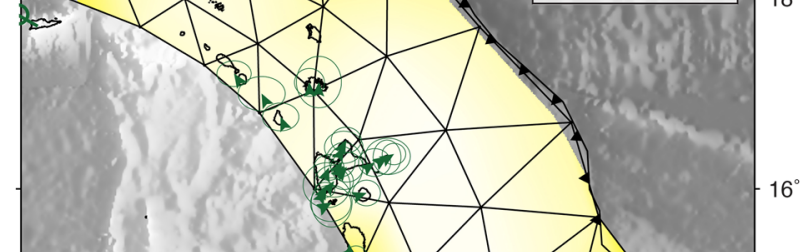

$16^{\circ}$
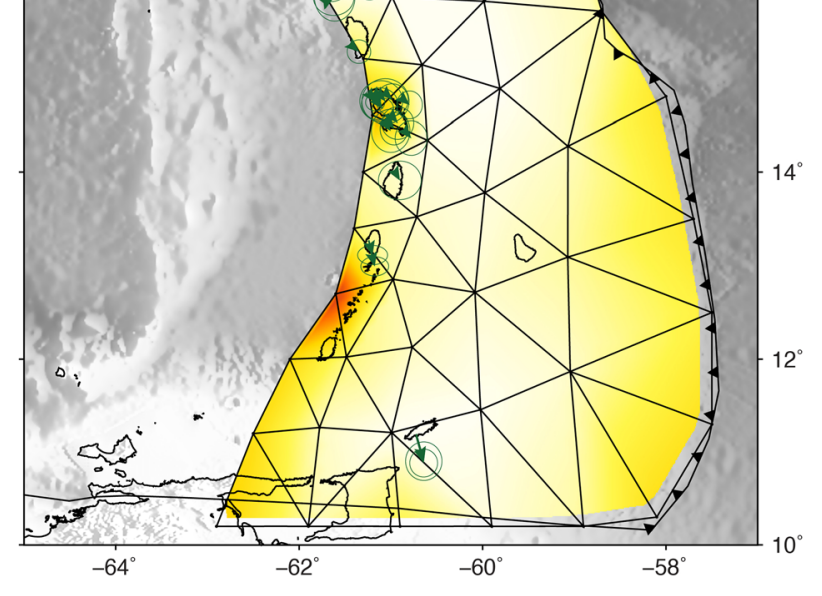

0.0

0.2

Interseismic coupling

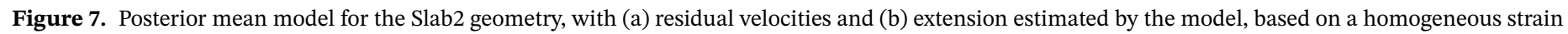

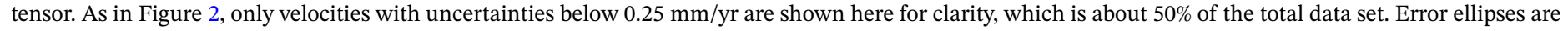
$95 \%$ confidence.

\subsection{The Role of Slab Geometry}

Previous studies that attempted to infer interseismic coupling along the Lesser Antilles subduction interface used a planar and constant fault geometry (e.g. $16^{\circ}$, Symithe et al., 2015). Uncertainties in subduction interface geometry are a limitation to our ability to accurately estimate interplate coupling (Paulatto et al., 2017). The recent, more detailed subduction interface models proposed by Hayes et al. (2018) and Bie et al. (2020), allow us to test how a change in fault geometry affects the posterior PDF of interseismic coupling inferred from the GPS data. This could be assessed from the posterior PDF using the approach of Ragon et al. (2018), but we prefer to directly show the difference between two models with two plausible geometries rather than lumping this effect within the posterior PDF.

Figure 8 shows the mean and mode posterior coupling estimates for both geometries, as well as three depth profiles along sections of the arc, in order to highlight the differences in slab geometries. The geometry proposed by Bie et al. (2020) fits the local seismicity (i.e., the CDSA catalog) better and might therefore better represent the actual geometry of the Lesser Antilles slab. We however find that the difference of mean interseismic coupling between the two geometries is very small and that the two models are in very good agreement. Both models show very low to low coupling along most parts of the interface, except for the two local highs discussed previously. We observe slightly larger uncertainties in the model based on the Bie et al. (2020) geometry in the regions where this model becomes steeper than the Slab2 model and is therefore located further away from the GPS observations. 




Figure 8. Posterior mean and mode coupling for the Slab2 geometry versus the geometry proposed by Bie et al. (2020). Three depth profiles are indicated in the maps as dashed colored lines: red for the Slab2 geometry and blue for the Bie et al. (2020) geometry. Seismicity from the CDSA catalog (1972-2013) is plotted in gray. The yellow triangles indicate the locations where the profile intersects the volcanic arc. For a colorscale of interseismic coupling, see Figures 6 and 7.

\subsection{A Test of the 1839 and 1843 Earthquake Sources}

The overall low coupling found along the Lesser Antilles subduction interface in this study raises questions about the location and faulting mechanism of the 1839 and 1843 historical earthquakes. Assuming these events were thrusts along the subduction interface, current earthquake cycle models (e.g., Avouac, 2015) predict that the rupture areas should have healed and re-locked. In order to test whether we would detect such re-locking, we calculate the predicted velocities as a result of full locking of the proposed 1839 and 1843 rupture areas (Feuillet et al., 2011). For this, a refined mesh was used to accurately lock the plate interface segments associated with the 1839 and 1843 events. We then use the synthetic velocities, with the uncertainties of the observed data set, as input to the inverse model described above (Section 3.2). For this inversion stage, we use the same fault discretization as used before (Section 4.3), meaning that we cannot retrieve the same coupling pattern as was imposed in the forward model (i.e., with a locally refined mesh). The results with a similar fault discretization for both the forward model and inversion can be found in the supporting information (Figure S9).

Figure 9 shows the result of this forward model and inversion for the 1839 and 1843 events. Both the mean and mode posterior coupling estimates retrieve the coupling we imposed in the forward models. The areas updip of these locked regions also show some degrees of coupling, likely related to the lower sensitivity and therefore the reduced capacity of our model to correctly infer coupling in these distal regions. Overall, these results indicate that if the 1839 and 1843 rupture areas had re-locked, they should (1) induce westward interseismic velocities of up to $7 \mathrm{~mm} / \mathrm{yr}$ in Guadeloupe and Martinique that we do not observe in the GPS data, and (2) be detected as locked patches in the inverse models described above (Section 4.3). Since these central regions of the plate interface also have the highest sensitivity to the GPS data (Figure 4), it is unlikely that they were locked during the observation period. 

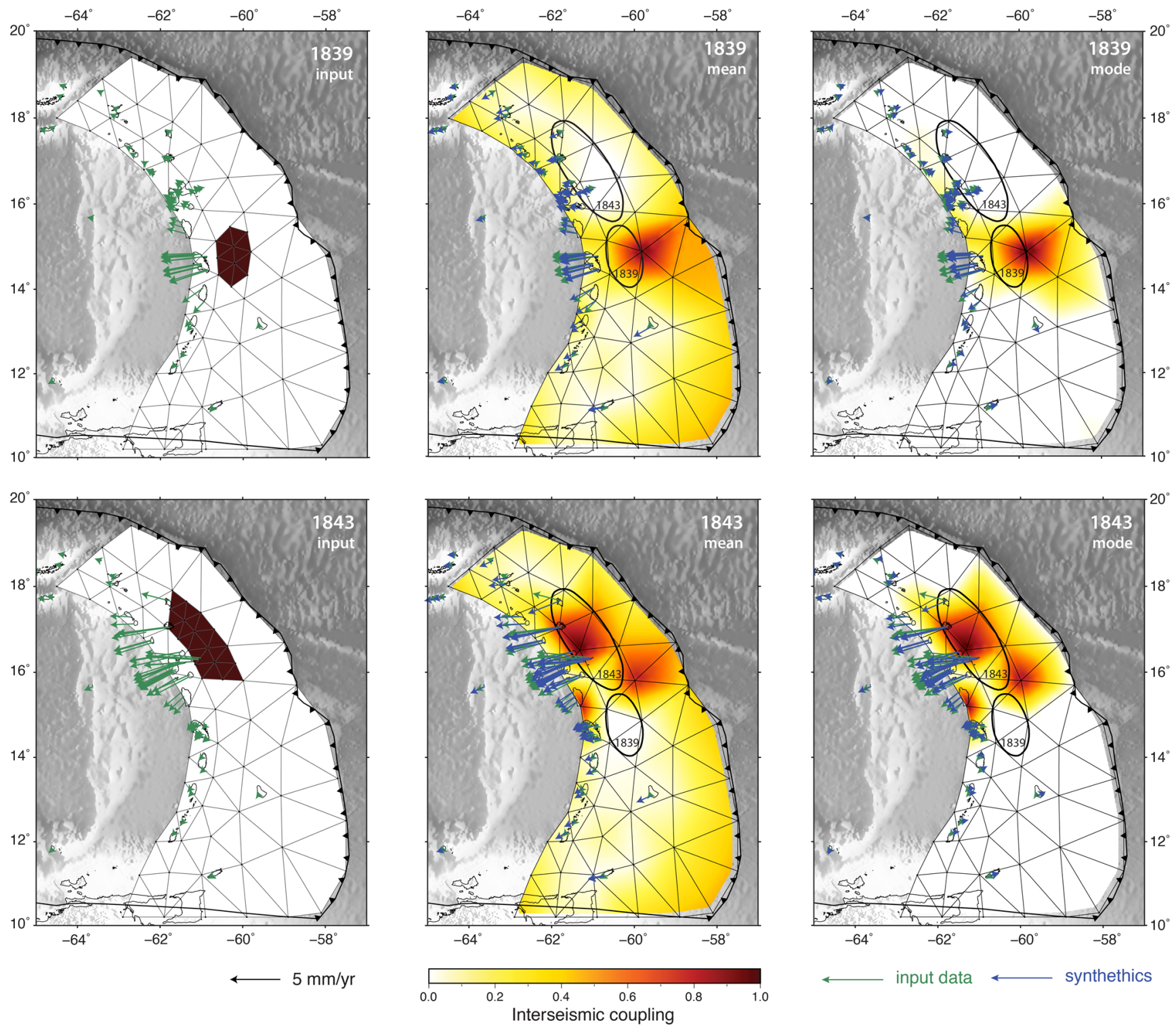

Figure 9. Forward model + inversion for the proposed 1839 and 1843 rupture areas. The panels show (from left to right) the forward models with the resulting GPS velocities (green arrows), and the mean and mode of the posterior probability density function. The synthetic velocities resulting from inferred coupling models are indicated with blue arrows.

\section{Discussion}

The sensitivity and forward model results (Figures 4 and 5) demonstrate that a total or partial locking of the subduction interface in the 20-65 km depth range would induce a plate boundary deformation signal with detectable, Caribbean-ward, velocities at the GPS sites on the Lesser Antilles islands. This is especially true in the northern part of the arc, where trench-to-island distances, ranging from 160 to $250 \mathrm{~km}$, are similar to Japan or South America, where strain accumulation as a consequence of a locked interface is recorded by the coastal GPS stations (e.g., Loveless \& Meade, 2010; Mazzotti et al., 2000; Nocquet et al., 2014). In the southern part of the Lesser Antilles arc, where slab dip decreases, the increasing trench-to-island distance is reflected in the reduced model sensitivity close to the trench (Figure 4). Forward and Bayesian inverse models, as well as the specific tests for the 1839 and 1843 events all show that the Lesser Antilles subduction interface currently has low to very low coupling. As a result, the active plate margin is unlikely to be building up elastic strain at a significant rate today. This low interplate coupling and low elastic strain accumulation 
rate raise questions about the nature of the 1839 and 1843 earthquakes, as well as the physical mechanism that is responsible for the low coupling we observe.

\subsection{What is the Nature of the 1839 and 1843 Events?}

Because of their magnitude and location at a subduction plate boundary, the 1839 and 1843 earthquakes are often considered as thrust events on the plate interface (Bernard \& Lambert, 1988; McCann \& Sykes, 1984). However, no direct evidence for this exists yet, and the magnitude and location of these historical events remain debated. Magnitude estimates for the 1843 event are mainly based on reported intensities. Early estimates range from 7.5 to 8.5, with estimated rupture lengths ranging from 100 to $300 \mathrm{~km}$ (Bernard \& Lambert, 1988; Feuillet et al., 2011; Hough, 2013; ten Brink et al., 2011). By including additional felt reports from the east coast of the United States, Hough (2013) proposed a magnitude of $M_{w} 8.4$ with values as high as $\mathrm{M}_{\mathrm{w}}$ 8.5-8.7 if the earthquake occurred farther offshore than its generally preferred location beneath the islands of Guadeloupe.

The absence of a tsunami or noticeable vertical deformation of the coasts of Guadeloupe or Antigua (Bernard \& Lambert, 1988) is conspicuous, since all $\mathrm{M}_{\mathrm{w}} \geq 8.4$ subduction megathrust event in the instrumental record resulted in a tsunami (National Geophysical Data Center/World Data Service, 2020), with maximum water heights ranging from 4.2 to $42 \mathrm{~m}$ (for events between $\mathrm{M}_{\mathrm{w}} 8.4$ to 8.7). Megathrust events that do not rupture the updip part of the subduction interface generally have smaller tsunamis, as illustrated by the $\mathrm{M}_{\mathrm{w}}$ 8.7 Nias Earthquake in 2005 (Briggs et al., 2006), that generated a tsunami with a run-up of $4.2 \mathrm{~m}$. A rupture of the deeper part of the plate interface only, as proposed for the Lesser Antilles 1843 event, could therefore generate a smaller tsunami than typically expected for such a large event. However, the lack of observations of even a small tsunami after a $\mathrm{M}_{\mathrm{w}}$ 8.4+ event remains peculiar. This, in combination with the very low coupling of the proposed rupture area found in this study, suggests that the 1843 event may have been characterized by either a smaller magnitude, or a source mechanism different from thrusting, and perhaps did not occur along the subduction interface.

The instrumental record shows that all $\mathrm{M}>7$ earthquakes of the Lesser Antilles in the past $\sim 70$ years have a normal faulting mechanism: $\mathrm{M} 7.5$ in 1953, $\mathrm{M}_{\mathrm{s}} 7.5$ in 1969, $\mathrm{M}_{\mathrm{s}} 7.4$ in 1974 and $\mathrm{M}_{\mathrm{w}} 7.4$ in 2007. Both the $M_{w}$ 7.4 2007 Martinique event and the M 7.5 1953 St. Lucia event have been interpreted as intraslab normal faulting earthquakes, that occurred at depths of 156 and $135 \mathrm{~km}$, respectively. A similar mechanism and depth are plausible for the 1839 event, which has a similar magnitude and occurred in the same region, characterized by dense intermediate-depth seismicity. Intraslab, normal faulting, and intermediate-depth earthquakes as large as $M_{w} 8.5$, if this was indeed the magnitude of the 1843 event, have however not been observed in the instrumental record. The 2019, $\mathrm{M}_{\mathrm{w}} 8.1$ intraslab and normal-faulting event at $110 \mathrm{~km}$ in Peru shows however that larger events can also occur at intermediate depths. Though of smaller magnitude than some of the estimates for the 1843, Lesser Antilles, earthquake, this event was felt all over South America (Jiménez et al., 2020; Ye et al., 2020), with macroseismic intensities at large distances that are similar to those reported for the 1843 Lesser Antilles event (e.g., IV MMI at 700 km distance, Hough, 2013; Jiménez et al., 2020). A large, intermediate-depth rupture would also explain the large felt extent of the 1843 event and the absence of a noticeable tsunami.

\subsection{What Physical Mechanism is Responsible for the Low Coupling?}

The subduction of topographic features has been proposed to play a role in tuning lateral variations of plate coupling and therefore mega-earthquake occurrence (e.g., Lallemand et al., 2018; Wang \& Bilek, 2014). In the Lesser Antilles, the subduction of fracture zones, or of oceanic ridges like the Barracuda Ridge and Tiburon Rise, have long been proposed to segment the seismogenic zone (McCann \& Sykes, 1984). More recent studies found that larger $b$-values, indicative of stress release through a higher fraction of small earthquakes, and low shear-wave velocities correlate with the location of incoming fracture zones on the American plates (Cooper et al., 2020; Schlaphorst et al., 2016). These authors relate this to excess dehydration due to fluids that are delivered into the subduction by the fracture zones. Such fluids along the plate interface will allow rupture at lower stress levels due to higher pore fluid pressures and hence increase the number of small earthquakes. Following that hypothesis, these incoming fracture zones and ridges facilitate 
stress dissipation through aseismic processes and should then act as "low coupling" areas. Such low coupling areas would then act as barriers to the propagation of megathrust earthquakes, hence limiting their magnitude. The assumption of a seismogenic segmentation by the incoming Tiburion Rise and Baracuda and Saint-Lucia ridges was also made by Hayes et al. (2014) to quantify the earthquake and tsunami potential of the Lesser Antilles subduction. However, the inversion of GPS velocities described above does not show variations in interseismic coupling that correlate with the presence of subducting ridges or fracture zones. Furthermore, since we find homogeneous low coupling along the entire subduction interface, it is unlikely that localized features play a dominant role here. Similarly, we do not observe large differences in coupling between the north and the south of the region, suggesting that the large difference in the amount of incoming sediments along the arc is not dominant in tuning the seismogenic behavior either.

Another characteristic of the Lesser Antilles, that holds for Puerto Rico as well, is the subduction of slowspread oceanic lithosphere formed along the Mid-Atlantic and Proto-Caribbean Ridges. Slow-spreading ridges create an oceanic lithosphere that is more heterogeneous in terms of thickness and composition, and more pervasively hydrated than their fast-spreading counterparts (Paulatto et al., 2017). As this hydrated oceanic lithosphere subducts, dehydration metamorphic reactions release fluids that migrate upwards, which could explain the high $V_{p} / V_{s}$ ratios (i.e., a proxy for high pore-fluid pressure) in the central part of the Lesser Antilles forearc (Martinique-Antigua; Paulatto et al., 2017). Increased pore-fluid pressures along the subduction interface reduce the effective normal stress and may therefore promote stable creep (Audet \& Schwartz, 2013; Bilek \& Lay, 2018; Moreno et al., 2014; Saffer \& Tobin, 2011). A negative correlation between interplate coupling and high $V_{p} / V_{s}$ ratios has indeed been observed before (Moreno et al., 2014), as well as a positive correlation between the amount of subducting fluids and the occurrence of intermediate-depth earthquakes (Faccenda et al., 2012; Hacker et al., 2003). A hydrated oceanic crust has also been associated with creep along the deeper parts of the subduction interface (i.e., in the $370^{\circ}-450^{\circ}$ temperature range), because a weak phyllosicilate-bearing mineralogy may allow the crust to creep at shear stresses low enough to accommodate significant plate interface displacement (Tulley et al., 2020). The subduction of fluid-rich slow-spread lithosphere is therefore an important candidate to explain the low coupling of the Lesser Antilles subduction inferred from GPS observations.

Looking at global subduction zones and seismogenic behavior, several other regions are thought to be mainly aseismic, such as the Aegean, Calabria, South Sandwich, and Mariana subduction zones (e.g., Carafa et al., 2018; Ruff \& Kanamori, 1983; Vanneste \& Larter, 2002; Vernant et al., 2014). These regions have in common their short length and strong curvature. In a global comparison of geometric subduction zone parameters with maximum megathrust earthquake magnitude, Schellart and Rawlinson (2013) found that stronger trench curvature correlates with fewer great megathrust earthquakes. The physical reason invoked is that rupture propagation over long distances is favored by a relatively planar subduction interface, but hindered by curved segments in subduction zones.

The lesser Antilles and Mariana subduction zones also share evidence for trench-parallel extension in the form of arc-perpendicular normal faults (Feuillet et al., 2002; Stern \& Smoot, 1998). In the Lesser Antilles, we are now able to document, from GPS observations, that this extension concerns the entire arc (Figure 7). In addition, the eastward (i.e., ocean-ward) GPS velocities observed in the central part of the Lesser Antilles arc show that an additional trench-perpendicular component of extension exists. In the Calabrian and Aegean subduction zones, forearc extension has been documented as well (Caputo et al., 2010; D'Agostino et al., 2011; Marsellos et al., 2010; Totaro et al., 2016), suggesting a possible link to the aseismic character of these four subduction zones. Extension in the overriding plate has been proposed to play a role in controlling the downdip limit of interseismic coupling (Wallace et al., 2012), and could therefore also be important in tuning the seismogenic behavior of subduction zones.

\section{Conclusions}

We provide a new assessment of interseismic coupling for the Lesser Antilles subduction zone, based on updated GPS velocities and the latest models of the slab geometry and elastic crustal structure. We use a Bayesian approach, allowing us to explore the entire range of plausible models and to provide realistic estimates of the state of coupling along the subduction interface. We find low to very low coupling along the entire 
plate interface, including in the proposed rupture areas of the 1839 and 1843 historical earthquakes. Given that $\sim 175$ years have passed since the 1843 event, current earthquake cycle models (e.g., Avouac, 2015; Savage, 1983) imply that the rupture area of a large interplate earthquake should have at least partially relocked today. This all questions the notion that these historical earthquakes were thrust events on the plate interface. While a further understanding of temporal variations in interseismic coupling needs to be addressed by future geodetic and geologic observations, our results indicate that the Lesser Antilles subduction zone is currently uncoupled. Under the paradigm that interseismic locking correlates with the location of large interplate earthquakes, as shown in an increasing number of studies (e.g., Chlieh et al., 2008; Loveless \& Meade, 2011; Moreno et al., 2010; Perfettini et al., 2010), this very low coupling is an indication that very large, Tohoku-like, events in the Lesser Antilles are unlikely_or must be very rare.

The GPS data also shows a small, but detectable amount of along-arc extension, consistent with geological observations of active normal faulting within the arc. The maximum extension rate reaches $0.70 \mathrm{~mm} / \mathrm{yr}$, which provides an upper bound for long-term slip rates of intra-arc active faults. All $\mathrm{M}>7$ earthquakes in the past $\sim 70$ years have been normal faulting events, either within the overriding plate or the subducting slab. Although the Lesser Antilles subduction appears to be mechanically uncoupled, implying little to no compressional strain accumulation along the subduction interface, such normal faulting events can however be very damaging and are an important hazard source in the Lesser Antilles.

The mechanism responsible for the lack of current mechanical coupling at the Lesser Antilles subduction remains elusive, but, as observed in other regions, may be related to the highly hydrated and fractured incoming oceanic lithosphere. As this hydrated oceanic lithosphere subducts, metamorphic dehydration reactions release large amounts of fluids that migrate to the plate interface where overpressures are maintained by a low permeability seal, hence promoting stable creep (Audet \& Schwartz, 2013; Moreno et al., 2014). This mechanism is consistent with the high $V_{p} / V_{s}$ ratios observed in the central part (Martinique-Antigua) of the Lesser Antilles subduction (Paulatto et al., 2017).

\section{Data Availability Statement}

This work uses data services provided by the UNAVCO Facility with support from the U.S. National Science Foundation (NSF) and National Aeronautics and Space Administration (NASA) under NSF Cooperative Agreement EAR-0735156. Permanent and episodic GPS within the OVSG, OVSM, and SRC footprint in the Lesser Antilles have been funded by CNRS-INSU-ACI programs originally, then through three FEDER European Community programs (CPER-PO and Interreg IV and V Caraïbe projects) cofunded by the

Acknowledgments

We thank Roland Bürgmann and one anonymous reviewer for their helpful and constructive comments. We also thank the agencies and individuals that made GPS data collection possible at the Observatoire Volcanologique Et Sismologique De Guadeloupe (OVSG) and Martinique (OVSM), at the Seismic Research Center (SRC) in Trinidad, and the French Insu-CNRS GPS instrument pool (gpscope.dt.insu.cnrs.fr). We thank the IGS and its centers, as well as UNAVCO, for providing open GNSS data and data products to the community. EvR and GPS campaigns were supported through the FEDER European Community program within the Interreg Caraïbes "PREST" project, to which this paper is a contribution. EC and RJ acknowledge support from the Institut Universitaire de France.

This project has received funding from the European Research Council (ERC) under the European Union's Horizon 2020 research and innovation program (Grant Agreement 758210, Geo4D project).
French Ministry of Research, the French Ministry of Environment, the Guadeloupe Regional Council, and the IPGP.

All data used in this work are openly available from the IGS (http://www.igs.org/), UNAVCO (www. unavco.org), and IPGP data center (http://volobsis.ipgp.fr/) archives. Ancillary information necessary to process GPS data, such as precise satellite orbits and antenna phase center models, is openly available from the IGS (http://www.igs.org). Global SINEX files used here are publicly available at MIT (acc.igs.org/reprocess.html). The software used to process the GPS data (GAMIT-GLOBK) is openly available at MIT (http:// geoweb.mit.edu/gg/). The codes that were used to obtain the geodetic coupling models are on Zenodo (Jolivet, 2020) but for the upto-date codes we refer readers to the versions of CSI (https://github.com/jolivetr/ csi) and AlTar (https://github.com/AlTarFramework/altar) on GitHub. Figures were produced using the Generic Mapping Tools software package (Wessel \& Smith, 1998).

\section{References}

Altamimi, Z., Rebischung, P., Métivier, L., \& Collilieux, X. (2016). ITRF2014: A new release of the International Terrestrial Reference Frame modeling nonlinear station motions. Journal of Geophysical Research: Solid Earth, 121(8), 6109-6131. https://doi. org/10.1002/2016JB013098

Audet, P., \& Schwartz, S. Y. (2013). Hydrologic control of forearc strength and seismicity in the Costa Rican subduction zone. Nature Geoscience, 6(10), 852-855. https://doi.org/10.1038/ngeo1927

Avouac, J.-P. (2015). From geodetic imaging of seismic and aseismic fault slip to dynamic modeling of the seismic cycle. Annual Review of Earth and Planetary Sciences, 43(1), 233-271. https://doi.org/10.1146/annurev-earth-060614-105302

Bernard, P., \& Lambert, J. (1988). Subduction and seismic hazard in the northern Lesser Antilles: Revision of the historical seismicity. Bulletin of the Seismological Society of America, 78(6), 1965-1983. 
Bie, L., Rietbrock, A., Hicks, S., Allen, R., Blundy, J., Clouard, V., et al. (2020). Along-arc heterogeneity in local seismicity across the Lesser Antilles subduction zone from a dense ocean-bottom seismometer network. Seismological Research Letters, 91(1), 237-247. https://doi. org/10.1785/0220190147

Bilek, S. L., \& Lay, T. (2018). Subduction zone megathrust earthquakes. Geosphere, 14(4), 1468-1500. https://doi.org/10.1130/GES01608.1

Bletery, Q., Thomas, A. M., Rempel, A. W., Karlstrom, L., Sladen, A., \& De Barros, L. (2016). Mega-earthquakes rupture flat megathrusts. Science, 354(6315), 1027-1031. https://doi.org/10.1126/science.aag0482

Bouysse, P., \& Guennoc, P. (1983). Donnees sur la structure de l'arc insulaire des Petites Antilles, entre Ste-Lucie et Anguilla. Marine Geology, 53(1-2), 131-166. https://doi.org/10.1016/0025-3227(83)90038-5

Bouysse, P., \& Westercamp, D. (1990). Subduction of Atlantic aseismic ridges and Late Cenozoic evolution of the Lesser Antilles island arc. Tectonophysics, 175(4), 349-380. https://doi.org/10.1016/0040-1951(90)90180-g

Braun, J. J., Mattioli, G. S., Calais, E., Carlson, D., Dixon, T. H., Jackson, M. E., et al. (2012). Focused study of interweaving hazards across the Caribbean. Eos, Transactions American Geophysical Union, 93(9), 89-90. https://doi.org/10.1029/2012eo090001

Briggs, R. W., Sieh, K., Meltzner, A. J., Natawidjaja, D., Galetzka, J., Suwargadi, B., et al. (2006). Deformation and slip along the Sunda megathrust in the great 2005 Nias-Simeulue earthquake. Science, 311(5769), 1897-1901. https://doi.org/10.1126/science.1122602

Brizzi, S., Sandri, L., Funiciello, F., Corbi, F., Piromallo, C., \& Heuret, A. (2018). Multivariate statistical analysis to investigate the subduction zone parameters favoring the occurrence of giant megathrust earthquakes. Tectonophysics, 728, 92-103. https://doi.org/10.1016/j. tecto.2018.01.027

Brown, K., \& Westbrook, G. (1987). The tectonic fabric of the Barbados Ridge accretionary complex. Marine and Petroleum Geology, 4(1), 71-81. https://doi.org/10.1016/0264-8172(87)90022-5

Caputo, R., Catalano, S., Monaco, C., Romagnoli, G., Tortorici, G., \& Tortorici, L. (2010). Active faulting on the island of Crete (Greece). Geophysical Journal International, 183(1), 111-126. https://doi.org/10.1111/j.1365-246x.2010.04749.x

Carafa, M. M. C., Kastelic, V., Bird, P., Maesano, F. E., \& Valensise, G. (2018). A "Geodetic Gap" in the Calabrian Arc: Evidence for a locked subduction megathrust? Geophysical Research Letters, 45(4), 1794-1804. https://doi.org/10.1002/2017gl076554

Chlieh, M., Avouac, J.-P., Sieh, K., Natawidjaja, D. H., \& Galetzka, J. (2008). Heterogeneous coupling of the Sumatran megathrust constrained by geodetic and paleogeodetic measurements. Journal of Geophysical Research, 113(B5), 1-31. https://doi.org/10.1029/2007jb004981

Chlieh, M., Perfettini, H., Tavera, H., Avouac, J.-P., Remy, D., Nocquet, J.-M., \& Bonvalot, S. (2011). Interseismic coupling and seismic potential along the Central Andes subduction zone. Journal of Geophysical Research, 116(B12), 1-21. https://doi.org/10.1029/2010jb008166

Cooper, G. F., Macpherson, C. G., Blundy, J. D., Maunder, B., Allen, R. W., Goes, S., et al. (2020). Variable water input controls evolution of the Lesser Antilles volcanic arc. Nature, 582, 525-529. https://doi.org/10.1038/s41586-020-2407-5

D'Agostino, N., D'Anastasio, E., Gervasi, A., Guerra, I., Nedimović, M. R., Seeber, L., \& Steckler, M. (2011). Forearc extension and slow rollback of the Calabrian Arc from GPS measurements. Geophysical Research Letters, 38(17), 1-6. https://doi.org/10.1029/2011gl048270

Das, S., \& Watts, A. (2009). Effect of subducting seafloor topography on the rupture characteristics of great subduction zone earthquakes. Subduction zone geodynamics (pp. 103-118). Heidelberg, Berlin: Springer-Verlag. https://doi.org/10.1007/978-3-540-87974-9_6

DeMets, C., Gordon, R. G., \& Argus, D. F. (2010). Geologically current plate motions. Geophysical Journal International, 181(1), 1-80. https://doi.org/10.1111/j.1365-246x.2009.04491.x

DeMets, C., Jansma, P. E., Mattioli, G. S., Dixon, T. H., Farina, F., Bilham, R., et al. (2000). GPS geodetic constraints on Caribbean-North America plate motion. Geophysical Research Letters, 27(3), 437-440. https://doi.org/10.1029/1999gl005436

De Min, L., Lebrun, J.-F., Cornée, J.-J., Münch, P., Léticée, J., Quillévéré, F., et al. (2015). Tectonic and sedimentary architecture of the Karukéra spur: A record of the Lesser Antilles fore-arc deformations since the Neogene. Marine Geology, 363, 15-37. https://doi. org/10.1016/j.margeo.2015.02.007

Duputel, Z., Agram, P. S., Simons, M., Minson, S. E., \& Beck, J. L. (2014). Accounting for prediction uncertainty when inferring subsurface fault slip. Geophysical Journal International, 197(1), 464-482. https://doi.org/10.1093/gji/ggt517

Faccenda, M., Gerya, T. V., Mancktelow, N. S., \& Moresi, L. (2012). Fluid flow during slab unbending and dehydration: Implications for intermediate-depth seismicity, slab weakening and deep water recycling. Geochemistry, Geophysics, Geosystems, 13(1), 1-23. https://doi. org/10.1029/2011gc003860

Feuillet, N., Beauducel, F., \& Tapponnier, P. (2011). Tectonic context of moderate to large historical earthquakes in the Lesser Antilles and mechanical coupling with volcanoes. Journal of Geophysical Research, 116(B10), 1-26. https://doi.org/10.1029/2011jb008443

Feuillet, N., Manighetti, I., Tapponnier, P., \& Jacques, E. (2002). Arc parallel extension and localization of volcanic complexes in Guadeloupe, Lesser Antilles. Journal of Geophysical Research, 107(B12), ETG 3-1-ETG 3-29. https://doi.org/10.1029/2001jb000308

Freymueller, J. T., \& Beavan, J. (1999). Absence of strain accumulation in the western Shumagin segment of the Alaska subduction zone. Geophysical Research Letters, 26(21), 3233-3236. https://doi.org/10.1029/1999gl008356

Freymueller, J. T., Cohen, S. C., \& Fletcher, H. J. (2000). Spatial variations in present-day deformation, Kenai Peninsula, Alaska, and their implications. Journal of Geophysical Research, 105(B4), 8079-8101. https://doi.org/10.1029/1999jb900388

Gonzáles, O., Clouard, V., Tait, S., \& Panza, G. F. (2018). S-wave velocities of the lithosphere-asthenosphere system in the Lesser Antilles from the joint inversion of surface wave dispersion and receiver function analysis. Tectonophysics, 734-735, 1-15. https://doi. org/10.1016/j.tecto.2018.03.021

Hacker, B. R., Peacock, S. M., Abers, G. A., \& Holloway, S. D. (2003). Subduction factory 2. Are intermediate-depth earthquakes in subducting slabs linked to metamorphic dehydration reactions? Journal of Geophysical Research, 108, 2030. https://doi.org/10.1029/2001jb001129

Hayes, G. P., McNamara, D. E., Seidman, L., \& Roger, J. (2014). Quantifying potential earthquake and tsunami hazard in the Lesser Antilles subduction zone of the Caribbean region. Geophysical Journal International, 196(1), 510-521. https://doi.org/10.1093/gji/ggt385

Hayes, G. P., Moore, G. L., Portner, D. E., Hearne, M., Flamme, H., Furtney, M., \& Smoczyk, G. M. (2018). Slab2, a comprehensive subduction zone geometry model. Science, 362(6410), 58-61. https://doi.org/10.1126/science.aat4723

Herring, T. (2003). MATLAB tools for viewing GPS velocities and time series. GPS Solutions, 7(3), 194-199. https://doi.org/10.1007/ s10291-003-0068-0

Herring, T., King, B., \& McClusky, S. (2010). Introduction to GAMIT/GLOBK Reference manual Global Kalman filter VLBI and GPS analysis program. Release 10.3. Cambridge: Massachusetts Institute of Technology.

Heuret, A., Conrad, C., Funiciello, F., Lallemand, S., \& Sandri, L. (2012). Relation between subduction megathrust earthquakes, trench sediment thickness and upper plate strain. Geophysical Research Letters, 39(5), 1-6. https://doi.org/10.1029/2011gl050712

Heuret, A., Lallemand, S., Funiciello, F., Piromallo, C., \& Faccenna, C. (2011). Physical characteristics of subduction interface type seismogenic zones revisited. Geochemistry, Geophysics, Geosystems, 12(1), 1-26. https://doi.org/10.1029/2010gc003230

Hough, S. E. (2013). Missing great earthquakes. Journal of Geophysical Research: Solid Earth, 118(3), 1098-1108. https://doi.org/10.1002/jgrb.50083 
Jany, I., Scanlon, K. M., \& Mauffret, A. (1990). Geological interpretation of combined Seabeam, Gloria and seismic data from Anegada Passage (Virgin Islands, north Caribbean). Marine Geophysical Researches, 12(3), 173-196. https://doi.org/10.1007/bf02266712

Jiménez, C., Luna, N., \& Moreno, N. (2020). Seismic source characteristics of the intraslab 2019 northern Peru earthquake ( $\left.M_{w} 8.1\right)$, Lima: National University of San Marco. https://bit.ly/3941p3f

Jolivet, R. (2020). CSI \& AlTAR. Paris: Zenodo (CERN). https://doi.org/10.5281/zenodo.3967788

Jolivet, R., Simons, M., Duputel, Z., Olive, J.-A., Bhat, H., \& Bletery, Q. (2020). Interseismic loading of subduction megathrust drives longterm uplift in northern Chile. Geophysical Research Letters, 47(8), 1-11. https://doi.org/10.1029/2019gl085377

Laigle, M., Becel, A., De Voogd, B., Sachpazi, M., Bayrakci, G., Lebrun, J.-F., et al. (2013). Along-arc segmentation and interaction of subducting ridges with the Lesser Antilles subduction forearc crust revealed by MCS imaging. Tectonophysics, 603, 32-54. https://doi. org/10.1016/j.tecto.2013.05.028

Lallemand, S., Peyret, M., van Rijsingen, E., Arcay, D., \& Heuret, A. (2018). Roughness characteristics of oceanic seafloor prior to subduction in relation to the seismogenic potential of subduction zones. Geochemistry, Geophysics, Geosystems, 19(7), 2121-2146. https://doi. org/10.1029/2018gc007434

Laurencin, M., Marcaillou, B., Graindorge, D., Klingelhoefer, F., Lallemand, S., Laigle, M., \& Lebrun, J.-F. (2017). The polyphased tectonic evolution of the Anegada Passage in the northern Lesser Antilles subduction zone. Tectonics, 36(5), 945-961. https://doi. org/10.1002/2017tc004511

Lin, Y., Jolivet, R., Simons, M., Agram, P., Martens, H. R., Li, Z., \& Lodi, S. (2015). High interseismic coupling in the Eastern Makran (Pakistan) subduction zone. Earth and Planetary Science Letters, 420, 116-126. https://doi.org/10.1016/j.epsl.2015.03.037

López, A. M., Stein, S., Dixon, T., Sella, G., Calais, E., Jansma, P., \& LaFemina, P. (2006). Is there a northern Lesser Antilles forearc block? Geophysical Research Letters, 33(7), 1-4. https://doi.org/10.1029/2005gl025293

Loveless, J. P., \& Meade, B. J. (2010). Geodetic imaging of plate motions, slip rates, and partitioning of deformation in Japan. Journal of Geophysical Research, 115(B2), 1-35. https://doi.org/10.1029/2008jb006248

Loveless, J. P., \& Meade, B. J. (2011). Spatial correlation of interseismic coupling and coseismic rupture extent of the $2011 M_{w}=9.0$ Tohoku-Oki earthquake. Geophysical Research Letters, 38(17), 1-5. https://doi.org/10.1029/2011gl048561

Manaker, D. M., Calais, E., Freed, A. M., Ali, S., Przybylski, P., Mattioli, G., \& De Chabalier, J. (2008). Interseismic plate coupling and strain partitioning in the northeastern Caribbean. Geophysical Journal International, 174(3), 889-903. https://doi. org/10.1111/j.1365-246x.2008.03819.x

Mann, P., Schubert, C., \& Burke, K. (1990). Review of Caribbean neotectonics. The Caribbean Region. The geology of North America (1990, pp. 307-338). Research supported by University of Texas, CONICIT, and Universidad de Los Andes, Boulder, Colo: Geological Society of America. https://doi.org/10.1130/dnag-gna-h.307

Marsellos, A., Kidd, W., \& Garver, J. (2010). Extension and exhumation of the HP/LT rocks in the Hellenic forearc ridge. American Journal of Science, 310(1), 1-36. https://doi.org/10.2475/01.2010.01

Masson, D., \& Scanlon, K. M. (1991). The neotectonic setting of Puerto Rico. Geological Society of America Bulletin, 103(1), 144-154. https://doi.org/10.1130/0016-7606(1991)103\%3C0144:tnsopr\%3E2.3.co;2

Mauffret, A., \& Leroy, S. (1997). Seismic stratigraphy and structure of the Caribbean igneous province. Tectonophysics, 283(1-4), 61-104. https://doi.org/10.1016/s0040-1951(97)00103-0

Mazzotti, S., Le Pichon, X., Henry, P., \& Miyazaki, S.-I. (2000). Full interseismic locking of the Nankai and Japan-west Kurile subduction zones: An analysis of uniform elastic strain accumulation in Japan constrained by permanent GPS. Journal of Geophysical Research, 105(B6), 13159-13177. https://doi.org/10.1029/2000jb900060

McCann, W. R., Dewey, J. W., Murphy, A. J., \& Harding, S. T. (1982). A large normal-fault earthquake in the overriding wedge of the Lesser Antilles subduction zone: The earthquake of 8 October 1974. Bulletin of the Seismological Society of America, 72(6A), $2267-2283$.

McCann, W. R., \& Sykes, L. R. (1984). Subduction of aseismic ridges beneath the Caribbean plate: Implications for the tectonics and seismic potential of the northeastern Caribbean. Journal of Geophysical Research, 89(B6), 4493-4519. https://doi.org/10.1029/JB089iB06p04493

Meade, B. J., \& Loveless, J. P. (2009). Block modeling with connected fault-network geometries and a linear elastic coupling estimator in spherical coordinates. Bulletin of the Seismological Society of America, 99(6), 3124-3139. https://doi.org/10.1785/0120090088

Metois, M., Vigny, C., \& Socquet, A. (2016). Interseismic coupling, megathrust earthquakes and seismic swarms along the Chilean subduction zone $\left(38^{\circ}-18^{\circ} \mathrm{S}\right)$. Pure and Applied Geophysics, 173(5), 1431-1449. https://doi.org/10.1007/s00024-016-1280-5

Minson, S., Simons, M., \& Beck, J. (2013). Bayesian inversion for finite fault earthquake source models I-Theory and algorithm. Geophysical Journal International, 194(3), 1701-1726. https://doi.org/10.1093/gji/ggt180

Moreno, M., Haberland, C., Oncken, O., Rietbrock, A., Angiboust, S., \& Heidbach, O. (2014). Locking of the Chile subduction zone controlled by fluid pressure before the 2010 earthquake. Nature Geoscience, 7(4), 292-296. https://doi.org/10.1038/ngeo2102

Moreno, M., Rosenau, M., \& Oncken, O. (2010). 2010 Maule earthquake slip correlates with pre-seismic locking of Andean subduction zone. Nature, 467(7312), 198-202. https://doi.org/10.1038/nature09349

Mouslopoulou, V., Oncken, O., Hainzl, S., \& Nicol, A. (2016). Uplift rate transients at subduction margins due to earthquake clustering. Tectonics, 35(10), 2370-2384. https://doi.org/10.1002/2016TC004248

Müller, R. D., Sdrolias, M., Gaina, C., \& Roest, W. R. (2008). Age, spreading rates, and spreading asymmetry of the world's ocean crust. Geochemistry, Geophysics, Geosystems, 9(4), 1-19. https://doi.org/10.1029/2007GC001743

Münch, P., Cornee, J.-J., Lebrun, J.-F., Quillevere, F., Verati, C., Melinte-Dobrinescu, M., et al. (2014). Pliocene to Pleistocene vertical movements in the forearc of the Lesser Antilles subduction: Insights from chronostratigraphy of shallow-water carbonate platforms (Guadeloupe archipelago). Journal of the Geological Society, 171(3), 329-341. https://doi.org/10.1144/jgs2013-005

National Geophysical Data Center/World Data Service (2020). NCEI/WDS global historical tsunami database.

Nocquet, J.-M., Villegas-Lanza, J., Chlieh, M., Mothes, P., Rolandone, F., Jarrin, P., et al. (2014). Motion of continental slivers and creeping subduction in the northern Andes. Nature Geoscience, 7(4), 287-291. https://doi.org/10.1038/ngeo2099

Patriat, M., Pichot, T., Westbrook, G., Umber, M., Deville, E., Benard, F., \& Party, A. C. (2011). Evidence for Quaternary convergence across the North America-South America plate boundary zone, east of the Lesser Antilles. Geology, 39(10), 979-982. https://doi.org/10.1130/ G32474.1

Paulatto, M., Laigle, M., Galve, A., Charvis, P., Sapin, M., Bayrakci, G., \& Kopp, H. (2017). Dehydration of subducting slow-spread oceanic lithosphere in the Lesser Antilles. Nature Communications, 8(1), 1-11. https://doi.org/10.1038/ncomms15980

Perfettini, H., Avouac, J.-P., Tavera, H., Kositsky, A., Nocquet, J.-M., Bondoux, F., et al. (2010). Seismic and aseismic slip on the Central Peru megathrust. Nature, 465(7294), 78-81. https://doi.org/10.1038/nature09062

Peterson, E. T., \& Seno, T. (1984). Factors affecting seismic moment release rates in subduction zones. Journal of Geophysical Research, 89(B12), 10233-10248. https://doi.org/10.1029/JB089iB12p10233 
Pichot, J. (2012). The Barracuda Ridge and Tiburon Rise, East of the Lesser Antilles: Origin, evolution and geodynamic implications, (Unpublished doctoral dissertation). Brest: l'Université de Bretagne Occidentale. Retrieved from http://hdl.handle.net/10068/893943

Raffaele, R. M. (2012). Seismic structure of subduction zone of the Lesser Antille, (Unpublished doctoral dissertation). Catania: Università di Catania. Retrieved from http://dspace.unict.it:8080/handle/10761/1256

Ragon, T., Sladen, A., \& Simons, M. (2018). Accounting for uncertain fault geometry in earthquake source inversions-I: Theory and simplified application. Geophysical Journal International, 214(2), 1174-1190. https://doi.org/10.1093/gji/ggy187

Reid, R. P., Carey, S. N., \& Ross, D. R. (1996). Late Quaternary sedimentation in the Lesser Antilles island arc. Geological Society of America Bulletin, 108(1), 78-100. https://doi.org/10.1130/0016-7606(1996)108\%3C0078:LQSITL\%3E2.3.CO;2

Reilinger, R., McClusky, S., Vernant, P., Lawrence, S., Ergintav, S., Cakmak, R., et al. (2006). GPS constraints on continental deformation in the Africa-Arabia-Eurasia continental collision zone and implications for the dynamics of plate interactions. Journal of Geophysical Research, 111(B5), 1-26. https://doi.org/10.1029/2005JB004051

Ruff, L., \& Kanamori, H. (1980). Seismicity and the subduction process. Physics of the Earth and Planetary Interiors, 23(3), 240-252. https:// doi.org/10.1016/0031-9201(80)90117-X

Ruff, L., \& Kanamori, H. (1983). Seismic coupling and uncoupling at subduction zones. Tectonophysics, 99(2-4), 99-117. https://doi. org/10.1016/0040-1951(83)90097-5

Ruiz, M., Galve, A., Monfret, T., Sapin, M., Charvis, P., Laigle, M., et al. (2013). Seismic activity offshore Martinique and Dominica islands (Central Lesser Antilles subduction zone) from temporary onshore and offshore seismic networks. Tectonophysics, 603, 68-78. https:// doi.org/10.1016/j.tecto.2011.08.006

Saffer, D. M., \& Tobin, H. J. (2011). Hydrogeology and mechanics of subduction zone forearcs: Fluid flow and pore pressure. Annual Review of Earth and Planetary Sciences, 39, 157-186. https://doi.org/10.1146/annurev-earth-040610-133408

Satake, K., \& Atwater, B. F. (2007). Long-term perspectives on giant earthquakes and tsunamis at subduction zones. Annual Review of Earth and Planetary Sciences, 35, 349-374. https://doi.org/10.1146/annurev.earth.35.031306.140302

Savage, J. C. (1983). A dislocation model of strain accumulation and release at a subduction zone. Journal of Geophysical Research, 88(B6), 4984-4996. https://doi.org/10.1029/JB088iB06p04984

Schellart, W. P., \& Rawlinson, N. (2013). Global correlations between maximum magnitudes of subduction zone interface thrust earthquakes and physical parameters of subduction zones. Physics of the Earth and Planetary Interiors, 225, 41-67. https://doi.org/10.1016/j. pepi.2013.10.001

Schlaphorst, D., Kendall, J.-M., Baptie, B., Latchman, J. L., \& Tait, S. (2017). Gaps, tears and seismic anisotropy around the subducting slabs of the Antilles. Tectonophysics, 698, 65-78. https://doi.org/10.1016/j.tecto.2017.01.002

Schlaphorst, D., Kendall, J.-M., Collier, J. S., Verdon, J. P., Blundy, J., Baptie, B., \& Bouin, M.-P. (2016). Water, oceanic fracture zones and the lubrication of subducting plate boundaries-insights from seismicity. Geophysical Journal International, 204(3), 1405-1420. https:// doi.org/10.1093/gji/ggv509

Schlaphorst, D., Melekhova, E., Kendall, J.-M., Blundy, J., \& Latchman, J. L. (2018). Probing layered arc crust in the Lesser Antilles using receiver functions. Royal Society Open Science, 5(11), 1807641-14. https://doi.org/10.1098/rsos.180764

Scholl, D. W., Kirby, S. H., von Huene, R., Ryan, H., Wells, R. E., \& Geist, E. L. (2015). Great ( $\left.\geq M_{w} 8.0\right)$ megathrust earthquakes and the subduction of excess sediment and bathymetrically smooth seafloor. Geosphere, 11(2), 236-265. https://doi.org/10.1130/GES01079.1

Song, T.-R. A., \& Simons, M. (2003). Large trench-parallel gravity variations predict seismogenic behavior in subduction zones. Science, 301(5633), 630-633. http://doi.org/10.1126/science.1085557

Speed, R., \& Larue, D. (1982). Barbados: Architecture and implications for accretion. Journal of Geophysical Research, 87(B5), 3633-3643. https://doi.org/10.1029/JB087iB05p03633

Stein, S., Engeln, J. F., Wiens, D. A., Fujita, K., \& Speed, R. C. (1982). Subduction seismicity and tectonics in the Lesser Antilles arc. Journal of Geophysical Research, 87(B10), 8642-8664. https://doi.org/10.1029/JB087iB10p08642

Stein, S., Engeln, J. F., Wiens, D. A., Speed, R. C., \& Fujita, K. (1983). Slow subduction of old lithosphere in the Lesser Antilles. Tectonophysics, 99(2-4), 139-148. https://doi.org/10.1016/0040-1951(83)90099-9

Stern, R. J., \& Smoot, N. C. (1998). A bathymetric overview of the Mariana forearc. Island Arc, 7(3), 525-540. https://doi. org/10.1111/j.1440-1738.1998.00208.x

Stevens, V., \& Avouac, J.-P. (2016). Millenary $M_{w}>9.0$ earthquakes required by geodetic strain in the Himalaya. Geophysical Research Letters, 43(3), 1118-1123. https://doi.org/10.1002/2015GL067336

Symithe, S., Calais, E., De Chabalier, J., Robertson, R., \& Higgins, M. (2015). Current block motions and strain accumulation on active faults in the Caribbean. Journal of Geophysical Research: Solid Earth, 120(5), 3748-3774. https://doi.org/10.1002/2014JB011779

ten Brink, U. S., Bakun, W. H., \& Flores, C. H. (2011). Historical perspective on seismic hazard to Hispaniola and the northeast Caribbean region. Journal of Geophysical Research, 116(B12), 1-15. https://doi.org/10.1029/2011JB008497

Totaro, C., Orecchio, B., Presti, D., Scolaro, S., \& Neri, G. (2016). Seismogenic stress field estimation in the Calabrian Arc region (south Italy) from a Bayesian approach. Geophysical Research Letters, 43(17), 8960-8969. https://doi.org/10.1002/2016GL070107

Tulley, C. J., Fagereng, Å., \& Ujiie, K. (2020). Hydrous oceanic crust hosts megathrust creep at low shear stresses. Science Advances, 6(22), eaba1529. http://doi.org/10.1126/sciadv.aba1529

Uchida, N., \& Bürgmann, R. (2019). Repeating earthquakes. Annual Review of Earth and Planetary Sciences, 47, 305-332. https://doi. org/10.1146/annurev-earth-053018-060119

van Benthem, S., Govers, R., Spakman, W., \& Wortel, R. (2013). Tectonic evolution and mantle structure of the Caribbean. Journal of Geophysical Research: Solid Earth, 118(6), 3019-3036. https://doi.org/10.1002/jgrb.50235

Vanneste, L. E., \& Larter, R. D. (2002). Sediment subduction, subduction erosion, and strain regime in the northern South Sandwich forearc. Journal of Geophysical Research, 107(B7), EPM 5-1-EPM 5-24. https://doi.org/10.1029/2001JB000396

van Rijsingen, E., Lallemand, S., Peyret, M., Arcay, D., Heuret, A., Funiciello, F., \& Corbi, F. (2018). How subduction interface roughness influences the occurrence of large interplate earthquakes. Geochemistry, Geophysics, Geosystems, 19(8), 2342-2370. https://doi. org/10.1029/2018GC007618

Vernant, P., Reilinger, R., \& McClusky, S. (2014). Geodetic evidence for low coupling on the Hellenic subduction plate interface. Earth and Planetary Science Letters, 385, 122-129. https://doi.org/10.1016/j.epsl.2013.10.018

Villegas-Lanza, J. C., Chlieh, M., Cavalié, O., Tavera, H., Baby, P., Chire-Chira, J., \& Nocquet, J.-M. (2016a). Active tectonics of Peru: Heterogeneous interseismic coupling along the Nazca megathrust, rigid motion of the Peruvian Sliver, and Subandean shortening accommodation. Journal of Geophysical Research: Solid Earth, 121(10), 7371-7394. https://doi.org/10.1002/2016JB013080

Villegas-Lanza, J. C., Nocquet, J.-M., Rolandone, F., Vallée, M., Tavera, H., Bondoux, F., \& Chlieh, M. (2016b). A mixed seismic-aseismic stress release episode in the Andean subduction zone. Nature Geoscience, 9(2), 150-154. https://doi.org/10.1038/ngeo2620 
Wada, I., \& Wang, K. (2009). Common depth of slab-mantle decoupling: Reconciling diversity and uniformity of subduction zones. Geochemistry, Geophysics, Geosystems, 10(10), 1-36. https://doi.org/10.1029/2009GC002570

Wallace, L. M., Fagereng, Å., \& Ellis, S. (2012). Upper plate tectonic stress state may influence interseismic coupling on subduction megathrusts. Geology, 40(10), 895-898. https://doi.org/10.1130/G33373.1

Wang, K., \& Bilek, S. L. (2014). Invited review paper: Fault creep caused by subduction of rough seafloor relief. Tectonophysics, 610, 1-24. https://doi.org/10.1016/j.tecto.2013.11.024

Wang, K., \& Tréhu, A. M. (2016). Invited review paper: Some outstanding issues in the study of great megathrust earthquakes-The Cascadia example. Journal of Geodynamics, 98, 1-18. https://doi.org/10.1016/j.jog.2016.03.010

Wessel, P., \& Smith, W. H. (1998). New, improved version of Generic Mapping Tools released. Eos, Transactions American Geophysical Union, 79(47), 579. https://doi.org/10.1029/98EO00426

Ye, L., Lay, T., \& Kanamori, H. (2020). Anomalously low aftershock productivity of the $2019 M_{w} 8.0$ energetic intermediate-depth faulting beneath Peru. Earth and Planetary Science Letters, 549, 116528. https://doi.org/10.1016/j.epsl.2020.116528

Zhu, L., \& Rivera, L. A. (2002). A note on the dynamic and static displacements from a point source in multilayered media. Geophysical Journal International, 148(3), 619-627. https://doi.org/10.1046/j.1365-246X.2002.01610.x 